\title{
Molecular Genetic Approaches to the Analysis of Human Ophthalmic Disease
}

\author{
DAVID N. COOPER,${ }^{*}$ MARCELLE JAY,$\dagger$ SHOMI BHATTACHARYA $\ddagger$ and BARRIE \\ JAY $\dagger$ \\ London and Edinburgh
}

\begin{abstract}
Summary
In this review of the recent literature, the contribution that the new techniques of molecular genetics has made in the analysis and diagnosis of human ophthalmic conditions is presented and discussed. Among the disorders reviewed are X-linked retinitis pigmentosa, Norrie's disease, gyrate atrophy and retinoblastoma, and there are also sections on crystallins and visual pigments.
\end{abstract}

The advent of recombinant DNA technology has resulted in dramatic advances both in the analysis and in the diagnosis of human inherited disease ${ }^{1-3}$ as well as increasing our understanding of the underlying molecular defect. Many major disorders affecting the eye have a genetic basis, and a high proportion appear to show X-linked inheritance (Fig. 1). There are also many other inherited conditions, which while primarily affecting other tissues, also have ophthalmic consequences. It is not very surprising, therefore, to find that the new techniques have already been used in the analysis and diagnosis of a range of ophthalmic conditions. The contribution that molecular genetics has made in this area is presented and discussed; its progress to date is charted and its future potential in research into eye disease assessed. A broad approach has been adopted, placing the greatest emphasis upon those studies judged to have made the most significant contributions to this topic.

Recombinant DNA technology is both methodologically uniform and remarkably versatile. The discovery of restriction enzymes, the site specific endonucleases that allow us to cleave large DNA fragments at defined sites, together with the development of techniques to 'mass-produce' these frag- ments (DNA cloning), have together heralded a breakthrough in our approach to solving many biological problems.

The size of the human genome, $3 \times 10^{9}$ base pairs (bp), has for a long time been a considerable barrier to its detailed analysis. Our newfound ability to dissect the genome has greatly increased our knowledge of its structure and function both at a gross level and at the level of the gene. ${ }^{4}$ The genome contains many repetitive sequences, some of which are functional (e.g. ribosomal RNA genes), some of which are probably not. In addition there is also a substantial single copy component: DNA sequences which occur only once in the genome. A part of this, estimated to be about 5 per cent of the total DNA complement, comprises the coding portion of the genome, containing about 150,000 different gene sequences. Thus, even the smallest human chromosome, 21 , may well contain as many as 2,000 genes in its approximately 50 million bp.

Each individual gene differs not only with respect to its DNA sequence specifying the amino acid sequence of the protein product it encodes, but also with respect to its structure. Mapping of specific genes or DNA regions has been made possible by the discovery of restriction enzymes. When total genomic DNA, made from an easily accessible tissue

*Haematology Department, King's College Hospital School of Medicine, Denmark Hill, London SE5 8RX. $\dagger$ Department of Clinical Ophthalmology, Moorfields Eye Hospital, City Road, London EC1V 2PD. ¥MRC Clinical and Population Cytogenetics Unit, Western General Hospital, Edinburgh EH4 2XU.

Correspondence to: Dr. M. Jay, PhD, Department of Clinical Ophthalmology, Moorfields Eye Hospital, City Road, London EC1V 2PD. 


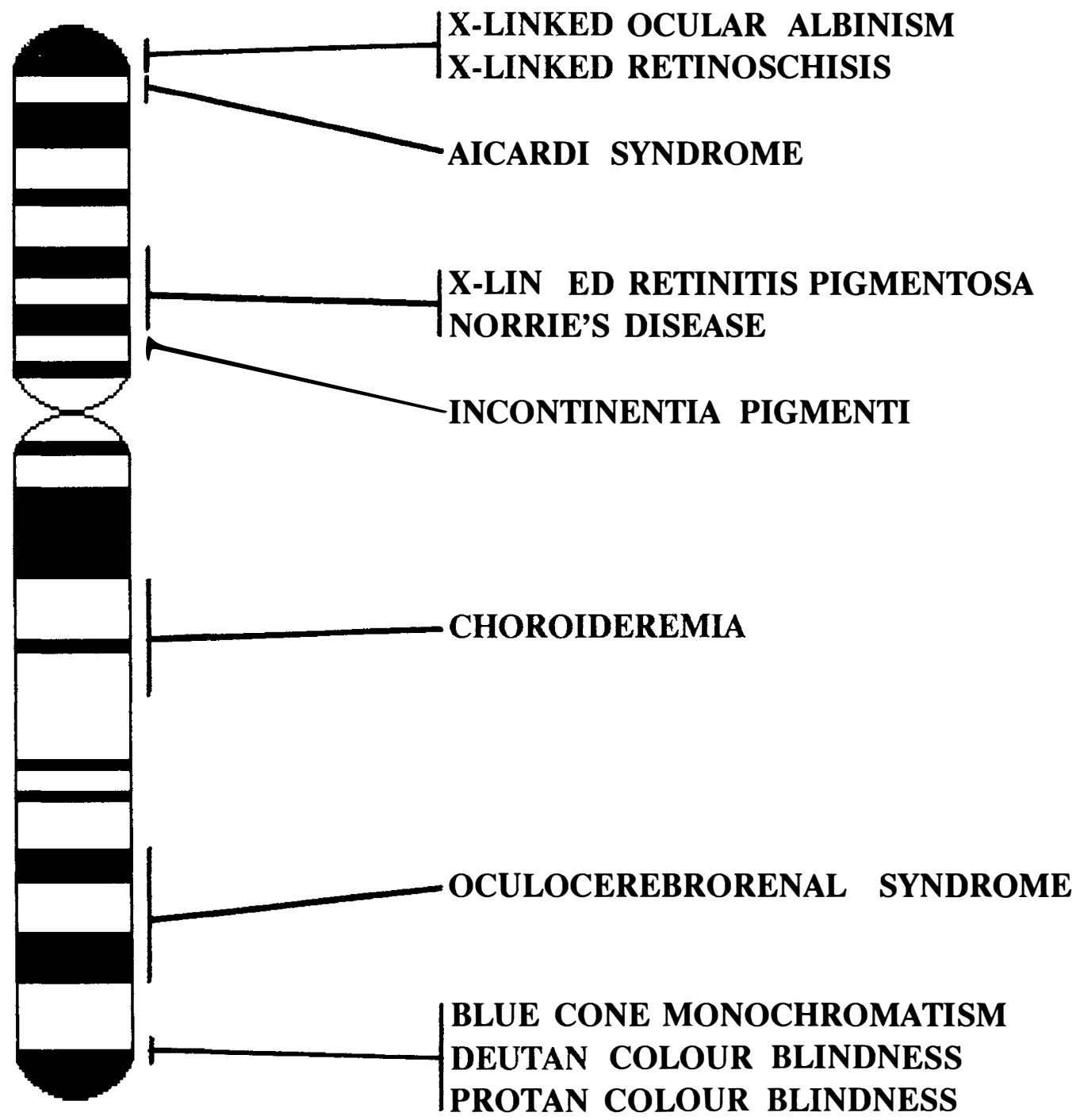

Fig. 1. Idiogram of human $X$ chromosome, showing locations of the X-linked ophthalmic disorders of major interest.

such as blood, is transferred from the agarose gel upon which it is size-fractionated, to a nitrocellulose membrane, it can be challenged with a radiolabelled probe (gene or DNA segment) to reveal the structure of the homologous region of DNA in the genome. This technique, known as 'Southern blotting' ${ }^{5}$ has now permitted the detection and analysis of many different pathological changes at the level of the gene.

Thus it is now known that most genes in higher organisms are not contiguous as originally thought, but are a complex mosaic of coding (exons) and non-coding (introns) sequences which must be processed to produce a mature RNA transcript. This processing involves the removal of introns in the original transcript followed by the splicing together of the exons. It is therefore evident that a considerable number of different levels exist at which regulation may occur, and hence an equal number of different levels at which an aberration within the gene may exert its pathological effects. Not surprisingly, the diversity of the mutations found to underlie genetic diseases has reflected the complexity 
of both the structure and regulation of human genes. ${ }^{6}$

Point mutations, insertions, deletions and rearrangements may all cause genetic disease by altering or even abolishing the activity of the gene product. Each may occur within a coding region, within an intron, in a messenger RNA (mRNA) splice junction, or each may alter or encompass specific sequences which perform a structural or regulatory function. Indeed, each may interrupt, alter, or otherwise interfere with any stage in the pathway of expression from gene to protein product.

Direct detection of the mutation underlying the disease state has now been accomplished in over 40 single-gene defects. ${ }^{1,2}$ For diagnospurposes, direct analysis is the most reliable, informative and hence most desirable means of detection. The absolute requirement for direct analysis is the possession of the appropriate gene (or oligonucleotide) probe. Deletions of a gene, or within a gene sequence, can be readily detected since the size of restriction fragments derived from that gene and detected by Southern blotting will be altered or even completely removed. A very small deletion may, however, remain undetectable if it does not result in the removal of a restriction site since electrophoretic resolution is limited. Point mutations that introduce or remove a restriction site will also alter the size of restriction fragments generated by a given enzyme. Where the point mutation has occurred outside a restriction site, the precise position and nature of the change may be determined by DNA sequencing. Ultimately, the mutant allele may be conveniently distinguished from its 'wild-type' counterpart by virtue of its differential hybridisation under specific conditions to a synthetic oligonucleotide complementary to a short region of DNA around the site of the mutation.?

If the gene deficit is not a gross deletion, then it may often go undetected due to the lack of a suitable restriction enzyme. In this case, restriction fragment length polymorphisms (RFLPs) around the gene may be used as chromosome markers in order to track the disease allele through a family pedigree. RFLPs are neutral changes in DNA sequence which are found frequently within normal populations. ${ }^{8}$ The vast majority of RFLPs are single base-pair changes that introduce or remove a restriction site, thus changing the mobility of DNA fragments as separated by gel electrophoresis. ${ }^{8}$ RFLPs identified by various $\mathrm{X}$ chromosome-specific probes and their map position are shown in Fig. 2. Although RFLPs will eventually permit the construction of a genetic linkage map of the entire human genome,${ }^{9}$ their importance in this context lies in their utility in permitting discrimination between the two chromosomes of each homologous pair. This provides the means to 'tag' the chromosome containing the disease allele and track it through multigenerational pedigrees.

This approach can also be employed to track disease alleles in cases where the disease gene has not been cloned and may not be known. Instead of a cloned gene, a polymorphic DNA segment from the same region of the chromosome is used as a marker. The first step is to establish linkage between the cloned polymorphic DNA segment (the 'marker' locus) and the disease locus. If linkage is tight, and therefore recombination events unlikely, this form of indirect analysis may be successfully employed to track the disease allele through multigenerational pedigrees. The possibility of error arises, however, due to the potential for a recombination event occurring between the marker and the disease locus. This error, and therefore the genetic distance between marker and disease loci, should be established before 'gene tracking' is applied diagnostically.

The tighter the linkage between the marker locus and the locus of interest, the smaller will be the number of recombinants as both loci tend to segregate together. Linkage analysis is then performed by applying likelihood methods to the common segregation of two or more loci. ${ }^{10}$ Briefly, a value of $\theta$, the recombination fraction, is derived such that the likelihood of obtaining the observed phenotypes is maximised. Comparison of the likelihood of linkage at a given value of $\theta$ with the likelihood of obtaining the observed phenotypes when the loci are unlinked $(\theta=0.5)$ permits either confirmation or exclusion of linkage on a statistical basis (the 'lod score'). By convention, a lod score of +3.00 is taken as evi- 


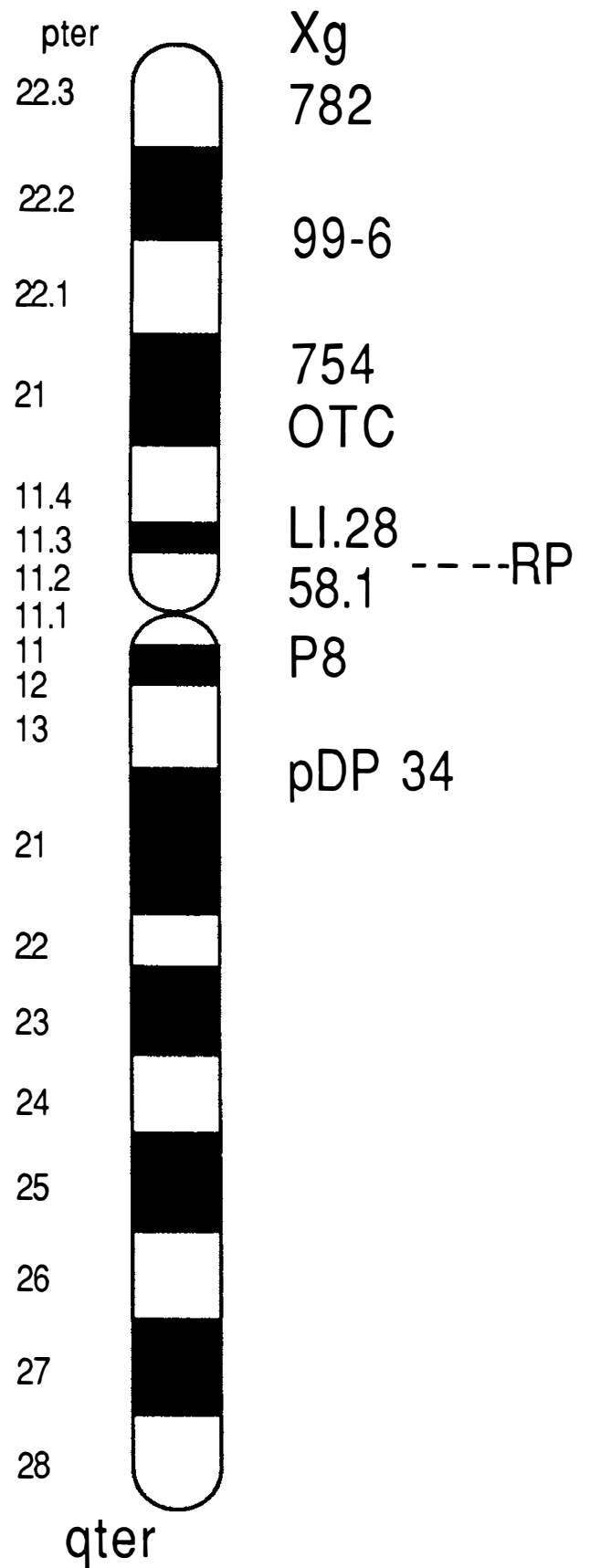

Fig. 2. Map position of probes used in linkage studies in retinitis pigmentosa and choroideremia.

dence for linkage, while a lod score of -2.00 is regarded as proof of independent segregation.

In molecular genetics, disease analysis and nosis are inextricably linked. Both may be possible if the appropriate cloned gene probe is available. If it is not, the establishment of close linkage will provide the basis of a diagnostic test long before the gene itself is isolated. A molecular biological explanation of an inherited disease state requires the prior localisation and isolation of the disease gene and the elucidation of its structure both at a gross level and at the level of the DNA sequence. Approaches and strategies towards these goals in the sphere of research into eye disease will be presented and discussed.

\section{Retinitis Pigmentosa (X-Linked)}

Retinitis pigmentosa is a group of disorders characterised by night blindness, constriction of the visual fields and characteristic changes in the fundi. There is genetic heterogeneity and, in the United Kingdom, the autosomal dominant form and the X-linked form comprise 24 per cent and 22 per cent respectively of the total cases observed. ${ }^{11}$ Linkage analysis has been applied so far only to the X-linked form. Molecular biological techniques are most easily applied to $\mathrm{X}$-linked disorders, firstly because a sex-linked pattern of inheritance obviates the need for a genome-wide search for the defective gene and secondly because the $\mathrm{X}$ chromosome is already saturated with cloned and regionally-localised polymorphic DNA segments which may be employed as linkage markers.

The $\mathrm{X}$-linked retinitis pigmentosa gene was first localised by Bhattacharya et al. ${ }^{12}$ by establishing linkage to an anonymous DNA segment L1.28 (DXS7). This sequence is a 1.25 kilobase (kb) single-copy genomic EcoRI fragment which has been assigned to the short arm of the $\mathrm{X}$ chromosome (Xp11.0-p11.3) ${ }^{13}$ and which detects polymorphic alleles $(9 \mathrm{~kb}$ or $12 \mathrm{~kb}$ ) with the restriction enzyme, TaqI. These authors, in their analysis of five families, found a maximum lod score of 7.89 at a recombination fraction, $\theta$, of 0.03 . While this then is the most likely distance between the marker and $\mathrm{X}$-linked retinitis pigmentosa locus, 95 per cent confidence limits for the location of the retinitis pigmentosa gene were given as $0-15$ centimorgans $(\mathrm{cM})$ from the DXS7 locus.

Further studies have now been carried out 
using the L1.28 clone. Nussbaum et al. ${ }^{14}$ tracked the $\mathrm{X}$-linked retinitis pigmentosa allele in a large Latin-American kindred in which the female carriers exhibited the tapetal reflex. There is considerable inter- and intrafamilial variation with respect to the tapetal reflex, and this sign was not seen in the families analysed by Bhattacharya et al. ${ }^{12}$ Linkage to L1.28 was nevertheless found, albeit rather looser $(\operatorname{lod} \max =2.54$ at $\theta=0.125 ; 95$ per cent probability limits, $0.05<\theta<0.32$ ).

Bhattacharya et al. ${ }^{15}$ have followed the inheritance of $\mathrm{X}$-linked retinitis pigmentosa and L1.28 in a large retinitis pigmentosa kindred with similar results (lod $\max =3.78$ at $\theta=0.09$ ). Mukai et al. ${ }^{16}$ in an analysis of four families, have estimated a lod max value of 2.29 to occur at a $\theta=0.10$.

The gene order of these loci on the X-chromosome was determined by applying threepoint linkage analysis to a large Danish pedigree using both the L1.28 probe and a C-banding heteromorphism (Xcen), thought to be a flanking marker. ${ }^{17}$ Genetic distances were estimated by pairwise lod score analysis and the map order given below is the most likely of the several alternatives:

Xcen --.-cc $11 \mathrm{cM}$ 6cM

Francke et al..$^{18}$ described a male patient with a small interstitial deletion of Xp21 who suffered from Duchenne muscular dystrophy, chronic granulomatous disease, McLeod syndrome and retinitis pigmentosa. The presence of a deletion was confirmed in this patient by the absence of hybridisation of his DNA to probe 754 (DXS84). However, the localisation of the $\mathrm{X}$-linked retinitis pigmentosa gene implied by this close association with Duchenne muscular dystrophy is inconsistent with linkage data from the above DXS7 studies. It was thus thought that either the cytological and genetic maps of this region were very different or that genetic heterogeneity existed in X-linked retinitis pigmentosa. Clayton et al. ${ }^{19}$ have argued against heterogeneity and suggest instead an error in diagnosis; indeed the clinical description of retinal dystrophy manifested by the patient of Francke et al. ${ }^{18}$ was unlike that normally encountered in $\mathrm{X}$-linked retinitis pigmentosa.
Buetow et al..$^{20}$ tested for genetic heterogeneity in X-linked retinitis pigmentosa, but the results were equivocal. Moreover, the method used to detect heterogeneity divided the sample on the basis of presence or absence of the tapetal reflex in female carriers. The occurrence of intra-familial variation for this phenotypic difference suggests that this division is artificial. Clayton et al. ${ }^{19}$ found no evidence of genetic heterogeneity in 13 families and combining data from all studies to date, reported a lod max of 14.01 at $\theta=0.08$. For the purposes of gene mapping at least, genetic heterogeneity need not be postulated for $\mathrm{X}$-linked retinitis pigmentosa.

For clinical purposes, however, Clayton et al. ${ }^{19}$ have argued that the question of heterogeneity must still be considered and a conservative estimate of risk should be calculated. These authors concluded that for families in which no recombination between L1.28 and X-linked retinitis pigmentosa has been observed, the mean risk is about 10 per cent for misdiagnosis. The mean risk is a more accurate measure of the risk to the individual being screened since it takes into account risk at values of $\theta$ other than at lod max. It follows that L1.28 should be useful for carrier detection and early diagnosis of $\mathrm{X}$-linked retinitis pigmentosa in the 40 per cent of cases in which the families are informative for variation at the DXS7 locus.

The proportion of families for which diagnosis is possible will be increased by the detection of additional high-frequency polymorphic variation at the DXS7 locus but only if no significant linkage disequilibrium (nonrandom association) with the known TaqI RFLP is present. Flanking markers and markers closer to the retinitis pigmentosa gene itself are also urgently needed to improve the reliability of diagnosis. This is because use of these markers will not only increase the probability of any one family being informative, but will also reduce the risk of misdiagnosis since errors in pedigree analysis would then be due solely to the occurrence of double crossovers. It should be stressed, however, that in addition to the possible existence of genetic heterogeneity, other sources of error will include the clinical diagnosis itself and non-paternity. ${ }^{17}$ 


\section{Choroideremia}

Choroideremia is another X-linked disorder in which males suffer progressive visual loss from childhood, resulting from profound atrophy of the choroid. Heterozygous females show little or no visual defect but usually exhibit a characteristic fundus appearance with spotty pigmentation in the midperiphery of the retina with focal areas of pigment epithelial atrophy. Molecular biological studies of this condition have adopted two approaches:

(1) linkage studies using polymorphic DNA segments as markers to track the disease, and

(2) the mapping and delineation of $\mathrm{X}$ chromosome deletions associated with the disease.

In practice, these approaches are often not mutually exclusive.

Nussbaum et al. ${ }^{21}$ studied three families and established linkage between the choroideremia locus and the polymorphic marker segment, DXYS1, localised to Xq13$q 21$. No recombinations were found between marker and disease locus and a lod max value of 5.78 was calculated at a recombination fraction, $\theta$, of 0.00 ( 90 per cent confidence limits, $0<\theta<0.09$ ). This finding has since been confirmed by Jay et al. ${ }^{22}$ (lod $\max =4.95$ at $\theta=0.00)$ and Sankila et al. ${ }^{23}(\operatorname{lod} \max =11.44$ at $\theta=0.00$ ).

Linkage was also found between choroideremia and the DNA segment DXS11 11,24 located at Xq24-q26 (lod $\max =1.54$ at $\theta=0.00 ; 90$ per cent confidence limits, $0.00<\theta<0.30$ ). This finding together with the absence of measurable linkage of choroideremia to the HPRT locus ${ }^{21}$ at Xq26-q27 suggested that the choroideremia locus may lie between DXYS1 and DXS11 in the region $\mathrm{Xq} 13-\mathrm{q} 24$. This postulate is now supported by the study of Jay etal. ${ }^{22}$ which analysed segregation data from 15 choroideremia families. These authors also reported segregation data for DXS14, DXS178 and DXS177 compatible with very loose linkage to the choroideremia locus. Close linkage between the DXYS12 locus (Xq13-q22) and choroideremia has been reported $(\operatorname{lod} \max =3.31 \text { at } \theta=0.00)^{23}$ but the linkage relationship to other markers is not yet known. In the absence of recombination between the disease and marker loci, no precise localisation of the disease locus can be obtained since genetic distance is a function of recombination frequency. However, Gal et al. ${ }^{25}$ using markers DXYS1 (Xq13-q21), DXS3 (Xq21.3-q22) and DXS11 (Xq24-q26) in two informative families, have reported recombinants and have suggested the map order shown below:

\section{Xcen-DXYS1-DXS3-choroideremia-DXS11-qter}

When the data of Gal et al. ${ }^{25}$ are combined with those of Nussbaum et al. ${ }^{21}$ the estimated genetic distances between markers DXYS1 and DXS11 and choroideremia are $8 \mathrm{cM}$ and $10 \mathrm{cM}$ respectively, ${ }^{25}$ i.e. $\theta$ at $\operatorname{lod} \max =0.08$ and 0.01 respectively. The reported close linkage of DXS3 to choroideremia (lod $\max =7.7$ at $\theta=0.03:{ }^{26} \operatorname{lod} \max =12.32$ at $\left.\theta=0.04\right)^{27}$ supports the validity of this map order.

The most detailed study to date is that of Lesko et al. ${ }^{28}$ which utilised 9 polymorphic DNA segments between Xp11.3 and Xq2.6 to derive a 'multipoint linkage map' of this region of the X chromosome. Multipoint linkage analysis provides the means to assess the linkage relationship of more than two markers simultaneously and is an extremely powerful tool in establishing gene order on the chromosome. In the study of Lesko et al., ${ }^{28} 6$ RFLP markers from the region $\mathrm{Xq} 13-\mathrm{Xq} 22$ were found to reside between 0 and $4 \mathrm{cM}$ away from the choroideremia locus. Multipoint linkage analysis suggested the most likely order to be:

Xcen --DXS1 --choroideremia --DXS17 --qter

in agreement with the data of Gal et al..$^{25}$ While maps of this kind should eventually permit clinical diagnosis, this is probably premature at this stage. This is because in the absence of recombination between some of the above markers and the choroideremia locus reported in three sizeable studies ${ }^{21-23}$ the question of genetic heterogeneity must, at least for the time being, remain open.

Studies such as those outlined above should permit antenatal diagnosis in families at risk of choroideremia using informative markers such as DXYS1. If the map order given above is confirmed and flanking markers can indeed 
be employed in linkage studies, then the reliability of diagnosis will be greatly enhanced. Although choroideremia is usually fairly rare, its prevalence in some populations may be very high, e.g. in Northern Finland. ${ }^{23}$ In this population, the disease occurs mainly in three large kindreds; the founder having been traced back 12 generations. ${ }^{23}$ It is possible that haplotype analysis of RFLPs associated with the linked DNA segment, DXYS1, will prove very useful for diagnosis in these kindreds.

A cytologically-detectable deletion associated with choroideremia encompassing the region Xq21 was described by Rosenberg et al. ${ }^{29}$ Using DNA segments from the region as hybridisation probes, these authors demonstrated that the DXYS1 locus, but not the DXS17 locus (Xq21.3-q22), was deleted. This further narrowed down the location of the choroideremia locus to Xq21.2-q21.33. In a more complete study of a family in which choroideremia was segregating with a deletion of sub-band Xq21.1, Hodgson et al. ${ }^{27}$ demonstrated that DNA sequences homologous to both DNA segments DXYS1 and DXS3 were absent in an affected male but present in a single dose in his mother and sister. Chorionic villus sampling and hybridisation of DXYS1 and DXS3 to fetal DNA permitted prenatal exclusion of choroideremia in the sister's unborn male fetus.

\section{Norrie's Disease}

This X-linked disorder presents with pseudotumours of the retina, retinal hyperplasia and necrosis of the inner layer of the retina, and cataract. Mental retardation is also fairly frequent.

Linkage studies to date have succeeded in establishing linkage between Norrie's disease and the locus DXS7 as defined by the TaqI RFLP detected with anonymous DNA segment L1.28 $8^{30,31}$ which has been localised to Xp11.3. No recombination has been found between DXS7 and the locus of Norrie's disease (lod $\max =3.81$ at $\theta=0.00)$. In addition, possible linkage was detected between the C-banding heteromorphism, Xcen, and Norrie's disease (lod $\max =1.99$ at $\theta=0.09$ ). Data for DXS16 (Xp22) were also compatible with loose linkage. The potential for antenatal diagnosis is good, but since no recombination events were detected between DXS7 and Norrie's disease, no estimate of genetic distance could be derived.

Two different deletions have so far been analysed using recombinant DNA methodology. Neither deletion was detectable cytologically and their existence was only demonstrated by the absence of hybridisation to the DXS7 probe. ${ }^{32,33}$ Obligate heterozygotes showed hybridisation band intensities consistent with hemizygosity at the DXS7 locus. In addition to DXS7, 9 cloned DNA sequences from the $\mathrm{Xp} 11-\mathrm{p} 21$ region were recruited in an unsuccessful attempt to delineate the boundaries of the deletion. ${ }^{33}$ Deletions, however, may not be a common cause of Norrie's disease since deletion of DXS7 was not found in a further 11 cases studied by Gal et al. ${ }^{33}$ It nevertheless remains possible that small deletions are frequent but do not necessarily encompass the DXS7 locus. In one of the above deletion studies, ${ }^{32}$ the prenatal exclusion of Norrie's disease in a male fetus of a carrier mother was demonstrated. Hybridisation of DXS7 to DNA derived from a chorionic villus sample from a male fetus confirmed that the fetus was unaffected.

\section{Hereditary Cataract and the Crystallin Gene Family}

Cataract is a generic term to describe a variety of conditions, both inherited and acquired, where the normally clear lens has become opaque. Cataract is also common in a variety of inherited conditions including Lowe's oculocerebrorenal syndrome, Norrie's disease, Usher's syndrome, retinitis pigmentosa, and Fabry's disease. ${ }^{34}$ Those cataracts recognised as being inherited have been known for many years to be heterogeneous and this was confirmed by conventional linkage studies. ${ }^{35-37}$ Linkage studies in affected families using RFLPs should identify the loci responsible and help unravel the heterogeneity seen clinically.

One approach to localise cataract loci would be a genome-wide search using arbitrary polymorphic DNA segments as markers to search for linkage with a given form of hereditary cataract. Since this is clearly very 
laborious, it is only sensible to test first (and if necessary exclude) all 'good' candidate genes before embarking upon such a search. One such candidate for involvement in hereditary cataract is the crystallin gene family. Since the crystallins have been very well reviewed elsewhere,$^{38-40}$ only a cursory description of the human genes will be given here.

The crystallins are a family of highly conserved lenticular proteins which, in humans, may be divided into three classes: alpha, beta, and gamma. The two alpha genes (alpha-A2 and alpha-B2) have been localised to chromosome 21 and 16 respectively, ${ }^{41}$ two of the beta genes (beta-A3/A1 and beta-B2) have been localised to chromosomes $17^{42}$ and 22 (M. Gorin, personal communication) respectively, while the gamma genes are clustered on the long arm of chromosome 2.43.44 The gamma crystallins are the best characterised of the human crystallins. A total of seven have been detected; five encode highly homologous gamma crystallin proteins, two are nonfunctional pseudogenes. ${ }^{45-47}$ Sequence comparison of the functional gamma crystallin genes have identified sequences $5^{\prime}$ to the genes which could be involved in the regulation of lens-specific gene expression. ${ }^{47}$

Lubsen et al..$^{48}$ adopted the candidate gene approach for Coppock cataract using a cloned gamma crystallin gene as a probe. Not only were they able to establish linkage (lod $\max =7.58$ at $\theta=0.00$ ) but they were also able to demonstrate that an RFLP haplotype (specific combination of RFLP alleles at adjacent sites on the same short stretch of chromosome) was specific to family members who suffered from cataract. This analysis does not prove that the aberrant gene causing Coppock cataract and the gamma-crystallin gene are one and the same. However, the two are necessarily very closely linked and this analysis does provide strong evidence for their identity. If this were not so and the two loci were located at a considerable distance from each other, the observed RFLP-haplotype associations would rapidly disappear within a few generations. ${ }^{49}$

Further evidence for the involvement of the crystallins in hereditary cataract has come from mouse studies. For example, cataracts in the Philly and Fraser mice have been attributed to a loss of beta and gamma crystallin mRNAs respectively. ${ }^{50.51}$ Moreover, a gamma-crystallin gene has been used as a probe to demonstrate the occurrence of a 50 per cent reduction in gamma-crystallin mRNA in the murine dominant cataract NOP (nuclear opacity) mutant. ${ }^{52}$

The testing of the remaining members of the crystallin multigene family in human pedigrees where other forms of hereditary cataract are segregating, is eagerly awaited. One good candidate appears to be the chromosome 21-encoded alpha-crystallin gene; cataract is commonly found in individuals with Down's syndrome (trisomy 21). Another possible candidate gene for hereditary cataract is the major intrinsic protein gene, now localised to chromosome $12 .^{53}$

\section{Gyrate Atrophy}

Gyrate atrophy is an autosomal recessive receptor dystrophy resulting in a progressive loss of vision due to sharply demarcated circular areas of chorioretinal atrophy. Patients with gyrate atrophy exhibit hyperornithinaemia and a deficiency of the mitochondrial enzyme, ornithine ketoacid aminotransferase. This enzyme catalyses the interconversion of ornithine and alpha ketoglutamate to pyrroline- 5 ' carboxylate and glutamate.

Two groups ${ }^{54.55}$ have isolated cDNA (copy DNA, made by reverse transcriptase from an expressed mRNA template) clones for ornithine aminotransferase. Using these clones as probes, the chromosomal genes have now been studied. The ornithine aminotransferase gene is a member of a gene family consisting of at least four copies on different chromosomes. ${ }^{56}$ Two loci have been found to be located on $10 \mathrm{q} 26$ and Xp11.2 by in situ hybridisation studies. ${ }^{57}$ The former is thought to be a functional gene and is a candidate for involvement in gyrate atrophy on account of its autosomal location.

The ornithine aminotransferase cDNA contains a 1,317 bp coding region, plus $44 \mathrm{bp}$ of $5^{\prime}$ and $654 \mathrm{bp}$ of $3^{\prime}$ untranslated sequences. ${ }^{54}$ It hybridises to a $2.2 \mathrm{~kb}$ poly $\mathrm{A}+$ mRNA species in liver, fibroblasts and lymphoblasts. Ramesh et al. ${ }^{54}$ studied seven patients with gyrate atrophy but failed to find 
any evidence for deletion or rearrangement of the ornithine aminotransferase genes using a total of 11 restriction enzymes. The absence of detectable mutation in the gene has also been reported by Inana et al. ${ }^{56}$ in their study of 24 patients with gyrate atrophy. Ramesh et al. ${ }^{54}$ also found the size and approximate amount of ornithine aminotransferase mRNA to be unaltered in the fibroblasts or lymphoblasts of their patients despite a concomitant 25-100 fold reduction in ornithine aminotransferase enzyme activity. However, Inana et al..$^{56}$ reported one example of a shortened ornithine aminotransferase mRNA and one of total absence of the mRNA in two of their patients with gyrate atrophy. Deletions therefore appear to be rare and the study of mutations at the ornithine aminotransferase locus will require the isolation and sequencing of mutant genes from patients with gyrate atrophy.

\section{Linkage Analysis and Other Eye Disorders}

Although most of the linkage studies carried out to date have involved one of the $\mathrm{X}$-linked diseases, retinitis pigmentosa, choroideremia or Norrie's disease, progress is also being made in other ophthalmic conditions.

One of these is $\mathrm{X}$-linked retinoschisis, characterised by foveal retinoschisis in all cases and true retinoschisis (intraretinal splitting) in about half. Wieacker et al. ${ }^{58}$ found some evidence for loose linkage between RC8 (DXS9), localised to Xp22, and X-linked retinoschisis (lod $\max =1.74$ at $\theta=0.15)$. Further analysis ${ }^{59}$ with linked probes from the short arm of the X-chromosome has also demonstrated loose linkage with DXS85 (Xp22.3-p22.2; lod $\max =0.91$ at $\theta=0.21$ ) and with DXS16 (Xp22; lod $\max =2.14$ at $\theta=0.11$ ). If these latter markers flank the locus for X-linked retinoschisis as proposed ${ }^{59}$ then, in combination, they may prove useful in diagnosis.

The Lowe oculocerebrorenal syndrome is a rare X-linked disorder characterised by congenital cataract, mental retardation and defective renal reabsorption. Since prenatal diagnosis has not, up to the present time, been possible and carrier testing uncertain, there was an urgent need to develop the means of tracking the syndrome with RFLPs. This has now been achieved by Silver et al. ${ }^{60}$ who have established close linkage between the Lowe syndrome and DXS10 (Xq26; lod $\max =6.45$ at $\theta=0.00)$ and between the Lowe syndrome and DXS42 (Xq24-qter, lod $\max =5.09$ at $\theta=0.00$ ) in an analysis of four affected families. It is still unclear whether DXS10 and DXS42 flank the Lowe syndrome locus. In the absence of recombinants, no genetic distances can be derived. However multipoint linkage analysis suggested that the most likely map order was:

\section{DXS17 ---Lowe syndrome ---DXS42 ---HPRT}

The Lowe syndrome locus itself is likely to be within the region Xq24-q26.

$\mathrm{X}$-linked ocular albinism has previously been shown to be linked to the $\mathrm{Xg}$ blood group on the short arm of the $\mathrm{X}$ chromosome ${ }^{61,62}$ More precise mapping of the ocular albinism locus should soon be possible as the first linkage data from anonymous DNA segment studies become available. DXS85 (Xp22.3-p22.2) has already been shown to be closely linked to the ocular albinism locus (lod $\max =4.60$ at $\theta=0.00){ }^{63}$

Linkage studies now appear to be under way for incontinentia pigmenti, ${ }^{64,65}$ a rare $\mathrm{X}$-linked dominant condition localised to $\mathrm{Xp} 11{ }^{66}$ and the Usher syndrome ${ }^{67}$ thought possibly to reside on chromosome 1 . Since the cloning of other genes of ophthalmic significance is now proceeding apace (e.g. G-proteins, retinol-binding protein, transducin etc), we may expect future studies of eye disease to utilise these as candidate gene loci.

\section{Molecular Genetics of Vision}

Rhodopsin, a light-absorbing pigment found in the retinal rods, is a member of the opsin gene family which also includes the visual pigment proteins found in the cones. Rhodopsin consists of an apoprotein, opsin, covalently bound to 11-cis retinal and is located in the disc membranes of the photoreceptor outer segment. The excitation of rhodopsin by light initiates the visual excitation process.

In 1983, Nathans and Hogness isolated both cDNA and genomic clones coding for bovine rhodopsin using a synthetic oligonucleotide (constructed by reference to the known amino acid sequence of the protein) as a probe. The 


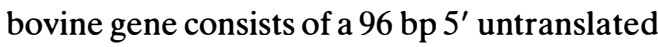
region, a $1,044 \mathrm{bp}$ coding region and a $1,400 \mathrm{bp} \mathrm{3}$ untranslated region. It is split into five exons by a total of $3.8 \mathrm{~kb}$ of intervening sequence and detects a $2.6 \mathrm{~kb}$ mRNA when used as a hybridisation probe in Northern blotting experiments.

The bovine gene was then used as a probe to isolate genomic clones for the human rhodopsin gene. ${ }^{68}$ The human gene is also split into five exons at exactly analogous positions and is 93.4 per cent homologous to bovine rhodopsin at the amino acid sequence level. The highest degree of homology is reserved for those residues that are potential phosphorylation or glycosylation sites or are involved in the binding of 11-cis retinal. For both bovine and human genes, 3 or 4 introns are immediately distal to the codons for putative transmembrane segments and one of these marks the boundary between the C-terminal and transmembrane domains. The correspondence between structure and function has important implications for theories of gene evolution.

Colour vision is made possible by the existence of three light-sensitive pigments, red, green and blue, which are located in the photoreceptor membranes of the cones. The visual pigments consist of an opsin moiety covalently linked to 11-cis-retinal and absorb light maximally at different wavelengths. This absorption is the step that triggers an enzyme cascade which ultimately ends in the production and transmission of a neural signal. Colour blindness, while not of great clinical significance, is remarkably common; some 8 per cent of Caucasian males exhibit red-green colour-blindness. The study of this anomaly nevertheless promises to unravel not only some of the complexities of the visual process but also to provide some insight into the mechanisms by which such variation is generated.

The genes for the human visual pigment proteins have now been cloned ${ }^{69}$ by virtue of their homology with rhodopsin. A rhodopsin gene probe was used to select clones from a human genomic library at low stringency. These were then separated into three distinct classes by restriction mapping of the cloned DNA. Finally, a human retinal cDNA library was screened for homologous clones corresponding to coding regions for the three classes of genomic sequences. Comparison of cDNA and genomic sequences permitted the mapping of the genes. One of the genes was found to be split into five exons, (cf. rhodopsin) interspersed with non-coding DNA (introns). This gene was identified as the bluepigment gene on account of its autosomal location (chromosome 7q22-->7qter). It has been sequenced and is 42 per cent homologous to rhodopsin at the amino acid sequence level.

Members of the other two classes of clones were mapped to the long arm of the X chromosome. The X-chromosomal location, identical to that of the genes for red-green colourblindness, argued strongly that these genes were indeed those coding for the red and green visual pigments. Red and green pigment cDNAs were both found to consist of 6 exons, all but the first being homologous to rhodopsin. ${ }^{69}$ They were found to be 96 per cent homologous at the amino acid sequence level and were distinguished firstly by restriction enzyme mapping and secondly by the comparison of genotype with phenotype. Males with normal colour vision have been shown to have one red and a variable number of green pigment genes, residing in a headto-tail tandem array within the $X$ chromosome. ${ }^{69}$

To correlate phenotype with genotype, Nathans etal. ${ }^{70}$ restriction mapped the red and and green pigment genes from males with different forms of colour vision abnormality and compared results with those derived from 'colour-normal' controls. G-R+ dichromacy (green sensitivity absent) correlated with the absence of one or more of the four EcoRI fragments homologous to the green pigment gene probe. Similarly, the $G+R-$ phenotype (red sensitivity absent) tended to be associated with the loss of one or more of the red pigment-associated EcoRI fragments. Initial studies of red-green colour-blindness were then extended to encompass anomalous trichromacy. Restriction enzyme mapping of the red and green pigment genes, together with gene quantitation analysis, indicated that these anomalies are caused not only by the absence or duplication of visual pigment gene 
loci but also in some instances by gene fusion resulting in the production of a hybrid protein. Such aberrations probably occur by unequal crossing-over or gene conversion and their high frequency is thought to be indicative of very close linkage of the red and green pigment genes on the $\mathrm{X}$ chromosome. Similar observations have been made on other genes which are both highly related and adjacent on the chromosome. Interestingly, the variation in gene copy number for the green pigment genes in 'colour-normal' males is not associated with any phenotypic difference.

Blue cone monochromatism, an uncommon X-linked disorder characterised by impaired visual acuity, poor colour discrimination, nystagmus and myopia, has recently been found to be linked to two marker loci, DXS15 and DXS52, both of which map to the vicinity of Xq28. ${ }^{71}$ Maximum likelihood estimates of the recombination fractions are 0.05 at a lod score of 3.58 (DXS15) and 0.07 at a lod score of 2.39 (DXS52). Psychophysical and electrophysiological tests demonstrate normal rod and blue cone function, with absence of red and green cone function. One possible explanation for these findings is that the structure of the red and green pigment genes has been altered beyond function or deleted. ${ }^{71}$

Comparison of the visual pigment genes at the amino acid sequence level has suggested that three genes, including those coding for rhodopsin and the blue pigment, were derived from a common ancestor gene, the third being duplicated perhaps around 30-40 million years ago to create the red and green pigment genes. ${ }^{69}$ Future study of the opsin gene family should therefore allow us not only to understand better the intricate molecular basis of vision, but also provide us with valuable insight into the mechanisms of gene mutation and evolution.

\section{Retinoblastoma}

Retinoblastoma is a malignant tumour of the retina occurring in infancy. It may be unilateral or bilateral, and some cases have a positive family history for the tumour. The genetics of retinoblastoma have been studied by Vogel, ${ }^{72}$ and non-hereditary retinoblastoma includes 85 per cent of unilateral cases in whom the tumour is unifocal. Hereditary retinoblastoma, which is transmitted as an autosomal dominant trait, includes all bilateral cases, all unilateral cases with multifocal tumours, and unilateral cases with a positive family history.

Deletion carriers with retinoblastoma often have other systemic abnormalities such as mental retardation. The deletions can usually be detected cytogenetically, and deletion mapping has shown that the region involved is band $13 q 14 .^{73-76}$ Both hereditary and nonhereditary retinoblastoma are considered to arise as a result of two mutations. Knudson ${ }^{77}$ proposed the 'two-hit' hypothesis whereby hereditary retinoblastoma arises from a germinal mutation followed by a somatic mutation, and non-hereditary retinoblastoma arises from two successive somatic mutations affecting both homologous chromosomes in the same target cell, the embryonic retinoblast. Thus, in hereditary retinoblastoma, the first mutation is thought to predispose to tumour formation. The first mutation may be a deletion, a point mutation, an insertion or a rearrangement; it alters or abolishes the activity of one of the retinoblastoma susceptibility loci on 13q14.

The second mutation affects the same locus on the homologous chromosome resulting in a 'loss of heterozygosity'. The second mutation may arise through chromosome loss, loss followed by reduplication, mitotic recombination, gene conversion, translocation, deletion, insertion or possibly point mutation. 78,79 Whichever mutation occurs, the result is the same, the loss of both normal retinoblastoma alleles and hemi- or homozygosity for the mutant allele. It is this change which is responsible for the retinoblastoma phenotype.

Deletions of the chromosomal region 13q14 have been found in the tumours of retinoblastoma patients with normal constitutional karyotypes,${ }^{80}$ suggesting a post-zygotic event. Deletion mosaicism, where some cell lines have a deletion and other cell lines are normal, has been found in the tumours of some patients with retinoblastoma. ${ }^{81,82}$

Since only 5 per cent of patients with retinoblastoma have a detectable chromosome deletion, ${ }^{72}$ the use of esterase $D$, an enzyme 
whose activity may be measured in all human tissues, has proved very useful in detecting deletions which had previously gone undetected. Esterase D was first mapped to chromosome 13 by van Heyningen and colleagues, ${ }^{83}$ then more precisely to $13 q 14$ by deletion mapping ${ }^{84}$ and genetic linkage studies. ${ }^{85,86,87}$ It has two isoenzymes; individuals may be homozygous for either E1 or E2, or heterozygous E1-E2. One interesting observation $^{88}$ was that in 6 patients, normal constitutional cells possessed both alleles, but in four patients, the tumour cells expressed only one allele. This may have been due to various mechanisms, including a deletion of the esterase D locus, or perhaps somatic inactivation of genes near the esterase $D$ and retinoblastoma loci.

The activity of esterase $\mathrm{D}$ is, as might be expected, proportional to the number of copies of the region $13 \mathrm{q} 14^{89}$ and is 50 per cent of normal if this region is deleted. Deletions of the esterase D locus occurred in about 5 per cent of 200 retinoblastoma cases reported by Cowell et al..$^{90}$ There have been reports ${ }^{91,92}$ of normal esterase $D$ levels in a patient with sporadic retinoblastoma and a deletion, suggesting that the breakpoints were situated between the two loci and that the esterase D locus is proximal to that of retinoblastoma.

Electrophoretic variants of esterase D may be used for antenatal diagnosis or for postnatal screening in the few families which appear to be informative.$^{93}$ In these families, affected individuals are heterozygous for the esterase D polymorphism, their partners being homozygotes. However, the frequency of the rare allele (E2) is low in the UK (0.116) and this limits the use of this test for antenatal diagnosis. ${ }^{94}$

RFLPs associated with DNA segments from the long arm of chromosome 13 have been used as markers to determine the extent of loss of heterozygosity at loci on this chromosome in tumour DNA. ${ }^{78,95}$ The specific mechanism of somatic mutation involved in the generation of hemi- or homozygosity in a given tumour can then be inferred from the extent and pattern of loss of heterozygosity observed when compared with that exhibited by constitutional chromosomes 13 from other tissues from the same individual. ${ }^{78,79,96,97}$ Thus in one case, RFLP patterns were consistent with the non-disjunctional loss of one chromosome 13 followed by the duplication of the remaining homologue, resulting in homozygosity for the mutant allele. ${ }^{78}$ The existence of a genetic map of chromosome $13^{98}$ is proving extremely useful in determining both the nature and the extent of the various chromosomal changes seen in retinoblastoma.

Loss of heterozygosity at chromosome 13 loci has also been implicated in osteosarcoma, ${ }^{99,100}$ a finding which suggests that the same locus may be involved in the genesis of different tumours in different tissues. Indeed the survivors of the hereditary form of retinoblastoma have a much higher likelihood of developing osteosarcoma than the general population, ${ }^{100,101}$ although the bone tumour may arise in some individuals in the absence of retinoblastoma. ${ }^{99}$ Similarly, loss of heterozygosity at chromosome 13 loci has also been observed in ductal breast tumours, ${ }^{102}$ where loss of one of the homologous chromosomes was thought to have occurred by mitotic nondisjunction. Some 5 per cent of cases of ductal breast carcinoma are thought to be inherited but it is not yet known whether the retinoblastoma/osteosarcoma locus is directly involved.

A large number of DNA clones have been isolated from chromosome $13^{103}$ and some have been used to map deletions in excess of $25 \mathrm{~kb}$ found in retinoblastoma patients. ${ }^{104,105}$ Three groups ${ }^{106-108}$ have now independently identified a putative candidate gene for retinoblastoma. The search strategies adopted were broadly similar; the cloning of genomic DNA sequence from the $13 q 14$ region by 'chromosome walking'. Chromosome walking refers to the isolation of overlapping DNA clones from a genomic library which can then in turn be used to isolate clones still further away from the original DNA probe. This process is then followed by the isolation of singlecopy DNA elements from the cloned region. Disease candidacy is then tested for on the basis that the retinoblastoma gene should be expressed in retinal cells but not in tumours. Both cDNA and genomic clones have been isolated, corresponding to a sequence which fitted this description. Restriction maps are reportedly similar for all three candidate gene 
probes. ${ }^{107,108}$

While an homologous mRNA of $4.6-4.7 \mathrm{~kb}$ was detected in retinal cells, ${ }^{106-108}$ a second mRNA species of size $2.3 \mathrm{~kb}$ was also found in fetal rat brain, ${ }^{107}$ raising the possibility of differential processing of the transcript. The retinoblastoma gene has now been sequenced and the protein sequence consisting of 816 amino acids (94 kilo Daltons) derived. ${ }^{107}$

Screening retinoblastoma DNA samples with the gene probe ${ }^{106-110}$ demonstrated the existence of fragments of altered size corresponding to partial deletions, fragments of reduced intensity (heterozygous deletions) and absent fragments (homozygous deletions), but changes were not observed in all cases. Lee et al. ${ }^{107}$ reported aberrant gene expression in 6 out of 6 retinoblastomas: four exhibited an mRNA transcript of reduced size and in two, no transcript was observed.

With one of the above probes, 7 out of 44 patients with bilateral or multifocal unilateral retinoblastoma and one with unifocal unilateral retinoblastoma were found to have a heterozygous deletion. ${ }^{110}$ Only 5 out of 8 of these deletions were detectable cytogenetically. Fung et al. ${ }^{108}$ examined 40 retinoblastomas using the retinoblastoma candidate cDNA as a probe. Sixteen of these exhibited partial or total deletion of the retinoblastoma gene, a frequency which provides encouragement for the use of this probe in antenatal diagnosis. Several cases of homozygous internal deletion were found, thus providing clear evidence for the authenticity of the retinoblastoma cDNA. In the 60 per cent of cases where no structural change was detectable, the mRNA transcript was either abnormal or absent. Finally, a homozygous internal deletion was also found in an osteosarcoma, providing good evidence that the osteosarcoma and retinoblastoma susceptibility genes are identical. The detection of more subtle mutations (e.g. point mutations within the coding sequence or promoter regions at the retinoblastoma/osteosarcoma locus) awaits the complete sequencing of the gene from retinoblastoma patients.

Formal confirmation that this CDNA is the recessive retinoblastoma gene must, however, await the demonstration that reversion can be induced by introduction of the wild- type retinoblastoma allele to tumour cells in culture. A model for this approach is provided by the introduction of a normal human chromosome 11 into a Wilms' tumour cell line which is reported to have brought about suppression of the tumour phenotype. ${ }^{111}$ An animal model may also be created. One way to do this would be to construct a 'transgenic' mouse by introducing an antisense retinoblastoma gene into the germline. The antisense mRNA, produced when this artificial gene is transcribed, would by definition bind tightly to the normal retinoblastoma mRNA, and in so doing, prevent its translation. In principle, this should mimic the loss or reduction of the retinoblastoma susceptibility gene transcript found in retinoblastoma. Such a model would be extremely useful for the biochemical and physiological characterisation of the pathological sequelae consequent to the presence of an aberrant retinoblastoma gene.

The human esterase D gene has recently been cloned, ${ }^{112,113}$ which has permitted direct analysis of the closely linked esterase D locus in retinoblastoma. Absence of esterase D activity in the retinoblastoma cells of one retinoblastoma patient has been shown to be due to the loss of one allele at the esterase D locus. ${ }^{114}$ While it is now clear that mutation at the esterase D locus is not a necessary accompaniment to the development of retinoblastoma, it is not yet certain whether the esterase D mutation reported by Lee et al.${ }^{114}$ is independent of that which caused the retinoblastoma or whether the two events are somehow causally linked. Horsthemke et al. ${ }^{110}$ found that 3 out of 8 deletions at the retinoblastoma locus did not encompass the esterase D locus.

Loss of heterozygosity at loci on chromosome 11 also seems to be important in the development of another embryonic tumour, Wilms' tumour. ${ }^{115-119}$ One in three children with sporadic (non-familial) aniridia develops Wilms' tumour. ${ }^{120,121}$ Since these conditions usually occur together in individuals with a deletion of $11 \mathrm{p} 13,124,125$, the association is thought to be due to the proximity of the two loci on chromosome 11. Michalopoulos et al. ${ }^{126}$ delineated the deletions in a patient with aniridia-Wilms' tumour. These authors found that the catalase locus, which maps to 
$11 \mathrm{p} 13$, was usually deleted but neither the proximal lactate dehydrogenase A locus nor the distal insulin, gamma-globin, Ha-Ras-1 or calcitonin loci were absent. Similarly, Van Heyningen et al. ${ }^{127}$ reported frequent deletion of the catalase gene in Wilms' tumour-aniridia while the calcitonin and beta-globin loci were unaffected. However, Boyd et al. ${ }^{128}$ using a catalase gene probe, have excluded deletions at the catalase locus in five patients with sporadic aniridia, one of whom had a cytologically observable deletion. The catalase gene is now thought to lie proximal to the Wilms' tumour-aniridia region. Glaser et al. ${ }^{129}$ have also reported the deletion of the gene encoding the beta subunit of follicle-stimulating hormone in patients with both aniridia and Wilms' tumour.

Two groups ${ }^{130,131}$ have recently reported elevated expression of insulin-like growth factor-II (IGF-II) in Wilms' tumour as compared with normal adult tissues. Although the observations were exciting in the light of other growth factors being implicated in oncogenesis, the level of IGF-II expression in tumours is comparable to that seen in embryonic tissues ${ }^{131}$ and appears to be independent of tumour progression in Wilms' tumour. ${ }^{132}$

Recently, it has been claimed that the alleles lost from tumour tissue are all maternal in origin. ${ }^{133}$ Since, however, the sample size was only 5 individuals, it will be necessary to examine a larger sample in order to confirm this potentially intriguing finding.

As with retinoblastoma, loss of heterozygosity on chromosome 11 is associated with more than one tumour. Embryonal tumours, hepatoblastoma and rhabdomyosarcoma, also exhibit acquired homozygosity at various loci on chromosome $11 .{ }^{134}$ While it seems clear that the Wilms' tumour and aniridia loci are probably distinct, it remains to be seen whether the genes causing the familial and sporadic forms of aniridia are the same. Mapping of the short arm of chromosome 11 by studies such as that of Porteous et al. ${ }^{135}$ and Mannens et al. ${ }^{136}$ should permit the localisation of the aniridia locus and aid the eventual isolation of the gene.

Loss of alleles on specific chromosomes has also been observed in bladder carcinoma (chromosome $11^{137}$ ), uveal melanoma (chromosome $2^{138}$ ), small cell lung cancer (chromosome $3^{139,140}$ ), renal cell carcinoma (chromosome $3^{141}$ ), acoustic neuroma (chromosome 22 ${ }^{142}$ ), meningioma (chromosome $22^{143}$ ), and familial adenomatous polyposis (chromosome $5^{144}$ ). A more general loss of heterozygosity occurs in malignant melanoma, where alleles were shown to be lost from no less than eight different chromosomes. ${ }^{145}$ Tumours like retinoblastoma thus appear to arise as a result of the functional loss of both normal alleles at the tumour locus, consistent with a model which invokes a suppressor role for normal alleles at this locus. ${ }^{79}$

The conceptual and methodological framework now exists within which to analyse other tumour states which may possess a similar aetiology to retinoblastoma and the Wilms' tumour-aniridia syndrome. Good candidates to fit such a model are tumours which are associated with chromosome deletions and which occur in both sporadic and familial forms. One of the most important contributions of RFLP analysis will be to help distinguish the sporadic from the familial cases with its important implications for prognosis, treatment and genetic counselling.

\section{Isolation of Disease Loci}

For molecular geneticists, the ultimate goal of disease analysis should be an explanation of the disease state at the molecular level. To this end, analysis of RFLPs associated with linked DNA segments is merely the first step towards the precise localisation, eventual isolation and finally the detailed analysis of the disease locus. Other approaches which may be helpful in furthering these aims and which are directly applicable to the analysis and diagnosis of eye disease, will therefore now be briefly discussed.

Initially, it was thought that it might be possible, once linkage had been established, to 'walk' along the chromosome towards the locus of interest. Chromosome 'walking' refers to the isolation of overlapping fragments from a genomic library which can then in turn be used to isolate additional fragments still further away from the site of the original DNA probe. This approach ${ }^{146}$ has proved successful for the mapping of regions of up to 
$100 \mathrm{~kb}$ around specific gene loci. However, progress proceeds in steps of only some $25 \mathrm{~kb}$ in a particular direction and success depends upon the absence of repetitive elements in the vicinity. Since most linked DNA segments are a minimum of several centimorgans from a disease locus (on average this genetic distance corresponds to several thousand kilobases of DNA) and repetitive DNA elements are virtually ubiquitous, other strategies are usually required.

One approach is to attempt to clone the breakpoint of a translocation found to be associated with the disease under study. Such a strategy has been demonstrated by Ray et al. ${ }^{147}$ who cloned sequences from the Duchenne muscular dystrophy (DMD) locus by using rRNA gene probes to isolate $\mathrm{X}$-chromosomal material adjacent to ribosomal DNA on an X:21 translocation chromosome. If the disease in question is associated with a deletion, then the most promising and direct way of isolating clones from the disease locus is that described by Kunkel et al. ${ }^{148}$ DNA from a Duchenne muscular dystrophy patient with a deletion at Xp21 was sheared and used in a 200-fold excess in a competitive reassociation reaction (PERT) with MboI-digested DNA derived from normal $\mathrm{X}$ chromosomes. The rationale of this technique is that only those unique Mbol fragments lacking homologous sequences in the patient's DNA were able to re-hybridise, thus re-creating their MboI 'sticky ends'. These fragments were then cloned into an appropriate vector; seven clones in all were isolated in this fashion ${ }^{148,149}$ and some of these were shown not to hybridise to DNA derived from Duchenne muscular dystrophy (DMD) patients with small deletions. ${ }^{150}$.

'Long-range restriction mapping'151 of regions of DNA, sometimes several thousand $\mathrm{kb}$ in length, has also begun to make a contribution. Mapping of such large regions has been made possible by the introduction of the new technique of pulsed field gel electrophoresis (PFG). PFG is able to resolve DNA fragments up to many thousands of $k b$ in size and it is this resolving power that provides the means to map very large regions of the chromosome. ${ }^{152,153}$ PFG has facilitated the more precise delineation of DMD-associated dele- tions and translocation breakpoints, ${ }^{154.155}$ and confirmed that the DMD gene covers a considerable area (about 2,000 kb) of the $X$ chromosome.

Further clones from the DMD locus have been isolated by virtue of their sequence conservation between man and mouse ${ }^{156}$ and one has identified a $16 \mathrm{~kb}$ mRNA in total RNA derived from human fetal muscle. ${ }^{156} \mathrm{cDNA}$ clones from the whole of the coding region have now been isolated ${ }^{157}$ and it will not be long before the entire sequence is known and the molecular basis of even the more subtle mutations causing Duchenne muscular dystrophy, elucidated.

Candidate genes for various other diseases have now also been isolated. These include chronic granulomatous disease, ${ }^{158}$ retinoblastoma, ${ }^{106-108}$ and cystic fibrosis. ${ }^{159}$ Strategies that were employed in the isolation of these genes have been reviewed by Orkin ${ }^{160}$ but some discussion is appropriate here.

Clearly, strategies will vary according to the presumed chromosome location of the disease gene, the amount of mapping data available, the applicability of different analytical techniques, the nature of mutations associated with the disease etc. As explained above, cytologically-detectable deletions or translocations associated with a disease state are of enormous help, both in helping to localise the disease gene, and in facilitating its eventual isolation. When these are not available, linkage data derived from segregation analyses using DNA segments or genes as markers, can be used to construct genetic maps of chromosomes. ${ }^{161}$ The availability of chromosomespecific DNA libraries ${ }^{162}$ should certainly facilitate the cloning of chromosomally localised disease genes. The advent of pulsedfield gel electrophoresis ${ }^{152}$ and associated new cloning technologies ${ }^{146,163-165}$ have now enabled the relatively rapid physical mapping of long stretches of DNA between such markers. For a long gene, a detailed map of the gene region is required for the accurate demarcation of deletion and translocation breakpoints, which may, as in Duchenne muscular dystrophy, have caused the disease. Such mapping information will also facilitate the further cloning of DNA fragments from the area of interest. For instance, PFG not 
only aids map construction but also permits the identification and separation of specific, very large DNA fragments encompassing the disease locus under study. Isolation of these fragments, followed by cloning of the entire region, will hasten the identification of the disease locus itself.

Even for a smaller gene, a physical map of the surrounding chromosomal region can prove immensely valuable for the localisation of putative coding regions through the detection of CG-rich 'HTF islands'. ${ }^{166}$ HTF (Hpa II tiny fragment) islands are not only rich in the dinucleotide CG, in contrast to the rest of the genome which is CG-depleted, but also unmethylated. Further, they are thought to be associated with gene sequences ${ }^{16-169}$ and may therefore potentially act as markers for their precise localisation. This strategy has now proved its worth by potentiating the precise localisation and isolation of, among others, a cystic fibrosis candidate gene. ${ }^{159}$

The cystic fibrosis study quoted above also illustrates the use that can be made of linkage disequilibrium data in assessing how close a candidate gene sequence may be to the disease gene itself. Linkage disequilibrium, or the non-random association of linked alleles, was found between RFLPs around the cystic fibrosis candidate gene and the disease phenotype for a large sample of cystic fibrosis patients. Interpretation of linkage disequilibrium data and its equation with physical distance is a pastime fraught with dangers but it is nevertheless possible to derive an estimate of the distance from the marker to the disease locus. Since linkage disequilibrium decays rapidly due to recombination, this is only appropriate over very short distances such as the $10 \mathrm{~kb}$ between marker and disease locus estimated by Estivill et al. ${ }^{159}$ The existence of linkage disequilibrium is therefore good $a$ priori evidence that the marker is very close (in molecular genetic terms) to the disease locus.

The location of coding sequences in the region of interest may also be helped by the detection of stretches of DNA in the region which are evolutionarily conserved. Conservation implies function and this in turn implies a coding sequence. Non-repetitive elements from a given human chromosomal region are subcloned and hybridised to DNA from other higher animals to look for sequence conservation.

Obviously, candidate genes must be expressed in appropriate tissues (e.g. the Duchenne muscular dystrophy gene in normal adult muscle) and the tissue pattern of expression will provide an important guide to the identity of the gene sequence. Conversely, 'enriched' cDNA, derived from, and specific to the tissue in which the defective gene would exert its pathological effects, may be used to find such genes.

Once we possess a copy of the disease gene itself, how do we use this to determine the nature of any one specific mutation in a given patient? As we have seen, deletions in excess of $100 \mathrm{bp}$ are readily detectable by Southern blotting. However, the majority of mutations causing genetic disease are probably undetectable using this method, and many may be single base-pair substitutions that do not alter restriction enzyme cleavage. One approach is therefore to make a gene library from DNA derived from the patient, isolate the gene by virtue of the homology with the cloned gene and then sequence it to search for the presumed base pair difference. Many examples of this type of approach are found in the literature. ${ }^{1.2}$

Various means are now available for the recognition of changes from a 'prototype' DNA sequence of a given gene which obviate the need for complete sequencing of the mutant gene. One alternative approach to the detection of single base-pair substitutions is that described by Myers. ${ }^{170}$ Heteroduplexes between a labelled single stranded betaglobin gene probe and fragments derived from denatured digests of genomic DNAs containing different beta-thalasaemia alleles were successfully separated and distinguished by denaturing gradient gel electrophoresis. Modifications of this basic technique have been reported ${ }^{171-173}$ and should together provide the potential to scan gene coding regions for single base-pair mismatches which, once localised, can then be further examined by DNA sequencing.

Another technique which promises greatly to aid mutant gene isolation is that reported by Scharf et al. ${ }^{174}$ and reviewed by Mullis $e t$ 
$a l .{ }^{175}$ The disease gene from the patient's genome is specifically amplified by a method known as the 'polymerase chain reaction'. Specific oligonucleotides, homologous to sequences upstream and downstream of the gene, are required to prime the reaction which consists of repetitive cycles of denaturation, primer annealing and polymerase extension, resulting in the amplification of the gene sequence of interest. Genes amplified in this way are present in such high copy number that they may be sequenced directly without the requirement of prior cloning.

Mutation in human genes appears to be non-random; some 35 per cent of single basepair substitutions causing human genetic disease occur in the dinucleotide cytosineguanine (CG) ${ }^{176}$ This is thought to be due to the propensity of cytosine, methylated at the 5 position, to undergo deamination to form thymidine. ${ }^{177,178}$ Over 90 per cent of the substitutions found in CG are cytosine to thymidine or guanine to adenine, consistent with this postulate. ${ }^{176}$

We suggest, therefore, the use of a directed strategy towards the localisation of specific mutations when the 'prototype' DNA sequence of the gene in question is known. Particular attention should be paid to CG dinucleotides in codons specifying amino acids within important (e.g. protein binding regions or proteolytic cleavage sites) regions of the protein product. Similarly CGA codons are potential hot spots for methylationinduced deamination. $\mathrm{A} C \rightarrow \mathrm{T}$ transition in this sequence will create a TGA termination codon with potentially deleterious consequences for the individual concerned. Since mutations at some sites are much more frequent than others, it follows that the use of directed search strategies, e.g. restriction enzymes which contain CG in their recognition sequence ${ }^{179}$ or oligonucleotides ${ }^{7}$ specific to predicted sites of mutation, can be expected to optimise the direct detection of gene mutations. A combination therefore of intelligent guesswork, combined with some of the techniques outlined above, should greatly ease the detection and characterisation of human gene mutations.

Eventually, however, proof of the involvement of a specific cloned gene must come from three sources. The first is the demonstration of a deletion internal to the region encompassed by the candidate cDNA or the detection of a single base-pair change within the coding region that is not an RFLP. The second is the absence or alteration of the mRNA corresponding to the cloned candidate gene probe in tissues from patients with the disease, which in healthy individuals, would express that mRNA. The third source of evidence (discussed in section on retinoblastoma) would be provided by phenotypic correction of the defect by reintroduction of the gene product thought to be lacking in the disease. When these requirements are fulfilled, we are considerably nearer to being able to define a disease in absolute terms and provide a molecular genetic explanation of the morbid pathology of the disease state.

The authors would like to thank Dr. Reuben Mibashan, Dr. John Clayton and Dr. John Cowell for their support and helpful comments.

\section{References}

${ }^{1}$ Cooper DN and Schmidtke J: Diagnosis of genetic disease using recombinant DNA. Hum Genet 1986, 73: 1-11.

${ }^{2}$ Cooper DN and Schmidtke J: Diagnosis of genetic disease using recombinant DNA-supplement. Hum Genet, (in press).

${ }^{3}$ Caskey CT: Disease diagnosis by recombinant DNA methods. Science 1987, 236: 1223-9.

${ }^{4}$ Lewin B: Gene Expression, Vol. 2, 2nd ed. New York, John Wiley, 1980.

${ }^{5}$ Southern EM: Detection of specific sequences among DNA fragments separated by gel electrophoresis. J Mol Biol 1975, 98: 503-17.

${ }^{6}$ Antonarakis SE, Kazazian H, Orkin SH: DNA polymorphism and molecular pathology of the human globin gene clusters. Hum Genet 1985, 69: $1-14$.

${ }^{7}$ Thein SL and Wallace RB: The use of synthetic oligonucleotides as specific hybridization probes in the diagnosis of genetic disorders. In Davies $\mathrm{KE}$ ed. Human genetic disease: a practical approach. Oxford, IRL Press, 1986.

${ }^{8}$ Cooper DN and Schmidtke J: DNA restriction fragment length polymorphisms and heterozygosity in the human genome. Hum Genet 1984, 66: $1-16$.

${ }^{9}$ Botstein D, White RL, Skolnick M, Davis RW: Construction of a genetic linkage map using restriction fragment length polymorphisms. Am J Hum Genet 1980, 32: 314-31.

${ }^{10}$ Bishop DT and Skolnick MH: Genetic markers and linkage analysis. In: Banbury report 14: recombinant DNA applications to human disease. Cold Spring Harbor Laboratory, 1983, 251-9. 
${ }^{11}$ Jay M: On the heredity of retinitis pigmentosa. $\mathrm{Br} J$ Ophthalmol 1982, 66: 405-16.

${ }^{12}$ Bhattacharya SS, Wright AF, Clayton JF, Price WH, Phillips C, McKeown CME, Jay M, Bird AC, Pearson PL, Southern EM, Evans HJ: Close genetic linkage between $\mathrm{X}$-linked retinitis pigmentosa and a restriction fragment length polymorphism identified by recombinant DNA probe L1.28. Nature 1984, 309: 253-5.

${ }^{13}$ Hofker MH, Wapenaar MC, Goor N, Bakker E, van Ommen GJB, Pearson PL: Isolation of probes detecting restriction fragment length polymorphisms from X-chromosome-specific libraries: potential use for diagnosis of Duchenne muscular dystrophy. Hum Genet 1985, 70: 14856.

${ }^{14}$ Nussbaum RL, Lewis RA, Lesko JG, Ferrell R: Mapping X-linked ophthalmic disease: II Linkage relationship of $\mathrm{X}$-linked retinitis pigmentosa to $\mathrm{X}$ chromosomal short arm markers. Hum Genet 1985a, 70: 45-50.

${ }^{15}$ Bhattacharya SS, Clayton JF, Harper PS, Hoare GW, Jay MR, Lyness AL, Wright AF: A genetic linkage study of a kindred with X-linked retinitis pigmentosa. Br J Ophthalmol 1985, 69: 340-7.

${ }^{16}$ Mukai S, Dryja TP, Bruns GAP, Aldridge JF, Berson EL: Linkage between the $\mathrm{X}$-linked retinitis pigmentosa locus and the L1.28 locus. Am J Ophthalmol 1985, 100: 225-9.

${ }^{17}$ Friedrich U, Warburg M, Wieacker P, Wienker TF, Gal A, Ropers H-H: X-linked retinitis pigmentosa: linkage with the centromere and a cloned DNA sequence from the proximal short arm of the X-chromosome. Hum Genet 1985, 71: 93-9.

${ }^{18}$ Francke U, Ochs HD, de Martinville B, Giacalone J, Lindgren V, Disteche C, Pagon RA, Hofker MH, van Ommen GJB, Pearson PL, Wedgwood RJ: Minor Xp21 chromosome deletion in a male associated with expression of Duchenne muscular dystrophy, chronic granulomatous disease, retinitis pigmentosa, and McLeod syndrome. Am J Hum Genet 1985, 37: 250-67.

${ }^{19}$ Clayton JF, Wright AF, Jay M, McKeown C, Dempster M, Jay BS, Bird AC, Bhattacharya SS: Genetic linkage between X-linked retinitis pigmentosa and DNA probe DXS7 (L1.28): further linkage data, heterogeneity testing and risk estimation. Hum Genet 1986, 74: 168-71.

${ }^{20}$ Buetow KH, Chakravarti A, Nussbaum RL, Ferrei RE: Sampling variance and confidence limits on the recombination value: XLRP and DXS7. Cytogenet Cell Genet 1985, 40: 595.

${ }^{21}$ Nussbaum RL, Lewis RA, Lesko JG, Ferrell R: Choroideremia is linked to the restriction fragment length polymorphism DXYS1 at Xq13-21. Am J Hum Genet 1985b, 37: 473-81.

22 Jay M, Wright AF, Clayton JF, Deans M, Dempster M, Bhattacharya SS, Jay B: A genetic linkage study of choroideremia. Ophthal Paediatr Genet 1986, 7: 201-4.

${ }^{23}$ Sankila E-M, De la Chapelle A, Karna J, Forsius H, Frants R, Eriksson A: Choroideremia: close linkage to DXYS1 and DXYS12 demonstrated by segregation analysis and historical-genealogical evidence. Clin Genet 1987, 31: 315-22.

${ }^{24}$ Lewis RA, Nussbaum RL, Ferrell R: Mapping $\mathrm{X}$-linked ophthalmic diseases: provisional assignment of the locus for choroideremia to Xq13q24. Ophthalmology 1985, 92: 800-5.

${ }^{25}$ Gal A, Brunsmann F, Hogenkamp D, Ruether K, Ahlert D, Wienker TF, Hammerstein W, Pawlowitzki IH: Choroideremia locus maps between DXS3 and DXS11 on Xq. Hum Genet 1986a, 73: 123-6.

${ }^{26}$ Lesko JG, Lewis RA, Ferrell R, Nussbaum RL: Choroideremia is tightly linked to two proximal $\mathrm{Xq}$ chromosome markers. Am J Hum Genet 1985, 37: A65.

${ }^{27}$ Hodgson SV, Robertson ME, Fear CN, Goodship J, Malcolm S, Jay B, Bobrow M, Pembrey ME: Prenatal diagnosis of $\mathrm{X}$-linked choroideremia with mental retardation associated with a cytologically detectable X-chromosome deletion. Hum Genet 1987, 75: 286-90.

${ }^{28}$ Lesko JG, Lewis RA, Nussbaum RL: Multipoint linkage analysis of loci in the proximal long arm of the human $\mathrm{X}$ chromosome: application to mapping the choroideremia locus. Am J Hum Genet 1987, 40: 303-11.

${ }^{29}$ Rosenberg T, Schwartz M, Niebuhr E, Yang H-M, Sardemann $\mathrm{H}$, Anderson $\mathrm{O}$, Lundsteen $\mathrm{C}$ : Choroideremia in interstitial deletion of the $\mathrm{X}$ chromosome: Ophthal Paediatr Genet 1986, 7: 205-10.

${ }^{30} \mathrm{Gal}$ A, Stolzenberger C, Wienker T, Wieacker P, Ropers H-H, Friedrich U, Bleeker-Wagemakers L, Pearson P, Warburg M: Norrie's disease: close linkage with genetic markers from the proximal short arm of the X chromosome. Clin Genet 1985b, 27: 282-3.

${ }^{31}$ Bleeker-Wagemakers L, Friedrich U, Gal A, Wienker TF, Warburg M, Ropers H-H: Close linkage between Norrie disease, a cloned DNA sequence from the proximal short arm, and the centromere of the X-chromosome. Hum Genet 1985, 71: 211-14.

${ }^{32}$ De la Chapelle A, Sankila E-M, Lindlof M, Aula P, Norio R: Norrie disease caused by a gene deletion allowing carrier detection and prenatal diagnosis. Clin Genet 1985, 28: 317-20.

${ }^{33}$ Gal A, Wieringa B, Smeets DFCM, Bleeker-Wagemakers L, Ropers H-H: Submicroscopic interstitial deletion of the $\mathrm{X}$ chromosome explains a complex genetic syndrome dominated by Norrie disease. Cytogenet Cell Genet 1986b, 42: 219-24.

${ }^{34}$ Clayton RM: Developmental genetics of the lens. In Maisel H, ed. The ocular lens: structure, function and pathology. New York, Marcel Dekker, 1985, p 90 .

${ }_{35}$ Coneally PM, Wilson AF, Merritt AD, Halveston EM, Palmer CG, Wang LY: Confirmation of genetic heterogeneity in autosomal dominant forms of congenital cataracts from linkage studies. Cytogenet Cell Genet 1978, 22: 295-7.

${ }^{36}$ Renwick JH and Lawler SD: Probable linkage between a congenital cataract locus and the 
Duffy blood group locus. Ann Hum Genet 1963 , 27: 67-84.

${ }^{37}$ Bateman JB, Spence MA, Marazita ML, Sparkes RS: Genetic linkage analysis of autosomal dominant congenital cataracts. Am J Ophthalmol 1986, 101: 218-25.

${ }^{38}$ Piatigorsky J: Lens crystallins and their gene families. Cell 1984, 38: 620-1.

${ }^{39}$ Piatigorsky J: Gene expression and genetic engineering in the lens. Invest Ophthalmol Vis Sci 1987, 28: 9-28.

${ }^{40}$ Lubsen NH, Renwick JH, Schoenmakers JGG: Hereditary cataract: perspective for prenatal screening. Ophthal Paediatr Genet 1986, 7: 195200.

${ }^{41}$ Quax-Jeuken Y, Quax W, van Rens G, Meera Khan $P$, Bloemendal $H$ : Assignment of the human alpha A-crystallin gene (CRYAI) to chromosome 21. Cytogenet Cell Genet 1985, 40: 727-8.

${ }^{42}$ Law ML, Cai G-Y, Kao F-T, Hogg D, Breitman M, Tsui L-C: Localization of a human beta-crystallin gene (CRYB1) to the long arm of chromosome 17. Cytogenet Cell Genet 1985, 40: 677 .

${ }^{43}$ Shiloh Y, Donlon T, Bruns G, Breitman ML, Tsui L-C: Assignment of the human $\alpha$-crystallin gene cluster (CRYG) to the long arm of chromosome 2, region q33-36. Hum Genet 1986, 73: 17-9.

${ }^{44}$ Den Dunnen JT, Jongbloed RJE, Geurts van Kessel AHM, Schoenmakers JGG: Human lens gamma-crystallin sequences are located in the p12-qter region of chromosome 2. Hum Genet 1985a, 70: 217-21.

${ }^{45}$ Meakin SO, Breitman ML, Tsui LC: Structural and evolutionary relationships among five members of the human gamma crystallin gene family. $\mathrm{Mol}$ Cell Biol 1985, 5: 1408-14.

${ }^{46}$ Den Dunnen JT, Moorman RJM, Cremers FPM, Schoenmakers JCG: Two human gamma-crystallin genes are linked and riddled with Alurepeats. Gene 1985b, 38: 197-204.

${ }^{47}$ Meakin SO, Du RP, Tsui L-C, Breitman ML: Gamma crystallins of the human eye lens: expression analysis of five members of the gene family. Mol Cell Biol 1987, 7: 2671-9.

${ }^{48}$ Lubsen NH, Renwick JH, Tsui L-C, Breitman ML, Schoemakers JG: A locus for a human hereditary cataract is closely linked to the $\alpha$-crystallin gene family. Proc Natl Acad Sci USA 1987, 84: 489-92.

${ }^{49}$ Cooper DN and Clayton JR: DNA polymorphism and the study of disease associations. Human Genet (In Press).

${ }^{50}$ Garber AT, Winkler C, Shinohara T, King CR, Inana G, Piatigorsky J, Gold RJM: Selective loss of a family of gene transcripts in a hereditary murine cataract. Science 1985, 227: 74-7.

${ }^{51}$ Carper D, Shinohara T, Piatigorsky J, Kinoshita JH: Deficiency of functional messenger RNA for a developmentally regulated $\alpha$-crystallin polypeptide in a hereditary cataract. Science 1982 , 217: 463-4.

52 Graw $\mathbf{J}$ and Winterhalter T: NOP-cataract in mice: altered transcription in lens gamma-crystallin mRNA. Abstracts, 13th International Congress of Biochemistry, Amsterdam 1985, p 647.

${ }^{53}$ Sparkes RS, Mohandas T, Heinemann C, Gorin MB, Horwitz J, Law ML, Jones CA, Bateman JB: The gene for the major intrinsic protein (MIP) of the ocular lens is assigned to human chromosome 12cen-q14. Invest Ophthalmol Vis Sci 1986, 27: 1351-4.

${ }^{54}$ Ramesh V, Shaffer M, Allaire J, Shih V, Gusella JF: Investigation of gyrate atrophy using a cDNA clone for human ornithine aminotransferase. DNA 1986, 5: 493-501.

${ }^{55}$ Inana G, Totsuka S, Redmond M, Dougherty T, Nagle J, Shiono T, Ohura T, Kominami E, Katanuma N: Molecular cloning of human ornithine aminotransferase. Proc Natl Acad Sci USA 1986, 83: 1203-7.

${ }^{56}$ Inana G, Hotta Y, Zintz C, Takki K, Kaiser-Kupfer M, Nakayasu K, Nakajima A, Shiono T: Analysis of ornithine aminotransferase gene and mRNA in gyrate atrophy patients. $A R V O$ Abstracts 1987, p18

${ }^{57}$ Barrett DJ, Bateman JB, Sparkes RS, Mohandas T, Kilisak I, Inana G: Chromosomal localisation of human ornithine aminotransferase gene sequences to chromosomes 10 and $\mathrm{X}$ : implications for hereditary retinal degenerations. ARVO Abstracts 1987, p19.

58 Wieacker P, Wienker JF, Dallapiccola B, Bennder $\mathrm{K}$, Davies KE, Ropers $\mathrm{H}-\mathrm{H}$ : Linkage relationships between retinoschisis, $\mathrm{Xg}$, and a cloned DNA sequence from the distal short arm of the $\mathrm{X}$ chromosome. Hum Genet 1983, 64: 143-5.

${ }^{59} \mathrm{Gal}$ A, Wienker TF, Davies K, Pearson PL, Kunkel LM, Latt SA, Willard HF, Ropers H-H: Further linkage studies between retinoschisis and cloned DNA sequences from the distal Xp. Cytogenet Cell Genet 1985a, 40: 634 .

60) Silver DN, Lewis RA, Nussbaum RL: Mapping the Lowe oculocerebrorenal syndrome to Xq24-q26 by use of restriction fragment length polymorphisms. J Clin Invest 1987, 79: 282-5.

${ }^{61}$ Fialkow PJ, Giblett ER, Motulsky AG: Measurable linkage between ocular albinism and $\mathrm{Xg}$. Am J Hum Genet 1967, 19: 63-9.

62 Pearce WG, Sanger R, Race RR: Ocular albinism and Xg. Lancet 1968, i: 1282-3.

${ }^{63}$ Kidd JR, Castiglione CM, Pakstis AJ, Sparkes RS, Gusella J, Davies K, Pearson P, Kidd KK: Close linkage of ocular albinism (OA) with DXS85 (p782) on the short arm of the X chromosome. Cytogenet Cell Genet 1985, 40: 667.

${ }^{64}$ Harris A, Lankester S, Soutter L, Bobrow M: Incontinentia pigmenti: Linkage studies using RFLPs. Abstracts, 7th International Congress of Human Genetics, Berlin, 1986, pp 630-1.

${ }^{65}$ Abdelaziz S, Hors-Cayla M-C, Gilgenkrantz S, Szpiro-Tapia S, Weber M, Heuertz S, Frezal J: Incontinentia pigmenti: clinical and biological studies. Abstracts, 7th International Congress of Human Genetics, Berlin, 1986, p 631.

${ }^{66}$ Cannizzaro LA and Hecht F: Gene for incontinentia pigmenti maps to band Xp11 with an $(\mathrm{X} ; 10)$ (p11:q22) translocation. Clin Genet 1987, 32: 66-9. 
${ }^{67}$ Pelias MZ, Lemoine DR, Wilson AF, Kossar AL, Elston RC: Linkage studies in Usher's syndrome: analysis of an Acadian kindred in Louisiana. Abstracts, 7th International Congress of Human Genetics, Berlin, 1986, pp 607-8.

${ }^{68}$ Nathans $\mathrm{J}$ and Hogness DS: Isolation, sequence analysis and intron-exon arrangement of the gene encoding bovine rhodopsin. Cell 1983, 34: 807-14.

${ }^{69}$ Nathans J, Thomas D, Hogness DS: Molecular genetics of human color vision: the genes encoding blue, green and red pigments. Science 1986a, 232: 193-202.

${ }^{70}$ Nathans J, Piantanida TP, Eddy RL, Shows TB, Hogness DS: Molecular genetics of inherited variation in human color vision. Science 1986b, 232: $203-10$.

${ }^{71}$ Lewis RA, Holcomb JD, Bromley WC, Wilson MC, Roderick TH, Hejtmancik JF: Mapping $\mathrm{X}$-linked ophthalmic diseases. III. Provisional assignment of the locus for blue cone monochromacy to Xq28. Arch Ophthalmol 1987, 105: 1055-9.

72 Vogel F: Genetics of retinoblastoma. Hum Genet 1979, 52: 1-54.

${ }^{73}$ Yunis JJ and Ramsay N: Retinoblastoma and subband deletion of chromosome 13. Am J Dis Child 1978, 132: 161-3.

${ }^{74}$ Strong LS, Riccardi VM, Ferrell RE, Sparkes RS: Familial retinoblastoma and chromosome 13 deletion transmitted via an insertional translocation. Science 1981, 213: 1501-3.

75 Johnson MP, Ramsay N, Carvenka J, Wang N: Retinoblastoma and its association with a deletion in chromosome 13; a survey using high resolution chromosome techniques. Cancer Genet Cytogenet 1982, 6: 27-37.

${ }^{76}$ Benedict WF, Murphree AL, Banerjee A, Spina CA, Sparkes MC, Sparkes RS: Patient with chromosome 13 deletion: evidence that the retinoblastoma gene is a recessive cancer gene. Science 1983, 219: 973-5.

${ }^{77}$ Knudson AG Jr: Mutation and cancer: statistical study of retinoblastoma. Proc Natl Acad Sci USA 1971, 68: 820-3.

${ }^{78}$ Cavenee WK, Dryja TP, Phillips RA, Benedict WF, Godbout R, Gallie BL, Murphree AL, Strong LC, White RL: Expression of recessive alleles by chromosomal mechanisms in retinoblastoma. Nature 1983, 305: 779-84.

${ }^{79}$ Murphree AL and Benedict WF: Retinoblastoma: clues to human oncogenesis. Science 1985, 223: 1028-33.

${ }^{80}$ Balaban G, Gilbert F, Nichols W, Meadows AT, Shields $\mathrm{J}$ : Abnormalities of chromosome 13 in human retinoblastoma from individuals with normal constitutional karyotypes. Cancer Genet Cytogenet 1982, 6: 213-21.

${ }^{81}$ Motegi T: Lymphocyte chromosome survey in 42 patients with retinoblastoma: Effort to detect 13 q14 deletion mosaicism. Hum Genet 1981, 58: 168-73.

${ }^{82}$ Motegi T: High rate of detection of $13 q 14$ deletion mosaicism among retinoblastoma patients (using more extensive methods). Hum Genet 1982, 61: 95-7.

${ }^{83}$ Van Heyningen V, Bobrow M, Bodmer WF, Gardiner SE, Povey S, Hopkinson DA: Chromosome assignment of some human enzyme loci. Mitochondrial malate dehydrogenase to 7, mannosephosphate isomerase and pyruvate kinase to 17, and probably, esterase D to 13. Ann Hum Genet 1975, 38: 295-303.

${ }^{84}$ Sparkes RS, Sparkes MC, Wilson MG, Towner JW, Benedict W, Murphree AL, Yunis JJ: Regional assignment of genes for human esterase D and retinoblastoma to chromosome band 13q14. Science 1980, 208: 1042-4.

${ }^{85}$ Connolly MJ, Payne RH, Johnson G, Gallie BL, Allderdice PW, Marshall WH, Lawton RD: Familial ESD-linked retinoblastoma with reduced penetrance and variable expressivity. Hum Genet 1983, 65: 122-4.

${ }_{86}$ Ward P, Packman S, Loughman W, Sparkes M, Sparkes R, Mcmahon A, Gregory T and Ablin A: Location of the retinoblastoma susceptibility gene(s) and the human esterase D locus. J Med Genet 1984, 21: 92-5.

${ }^{87}$ Sparkes RS, Murphree AL, Lingua RW, Sparkes MC, Field LL, Funderburk SJ, Benedict WF: Gene for hereditary retinoblastoma assigned to human chromosome 13 by linkage to esterase D. Science 1983, 219: 971-3.

${ }^{88}$ Godbout R, Dryja TP, Squire J, Gallie BL, Phillips RA: Somatic inactivation of genes on chromosome 13 is a common event in retinoblastoma. Nature 1983, 304: 451-3.

${ }^{89}$ Dryja TP, Bruns GAP, Gallie B, Petersen R, Green W, Rapaport JM, Albert DM, Gerald PS: Low incidence of deletion of the esterase D locus in retinoblastoma patients. Hum Genet 1983, 64: 151-5.

${ }^{90}$ Cowell JK, Rutland P, Jay M, Hungerford J: Deletions of the esterase D locus from a survey of 200 retinoblastoma patients. Hum Genet 1986, 72: 164-7.

${ }^{91}$ Sparkes RS, Sparkes MC, Kalina RE, Pagon RA, Salk DJ, Disteche CM: Separation of retinoblastoma and esterase D loci in a patient with sporadic retinoblastoma and $\operatorname{del}(13)$ (q14.1q22.3). Hum Genet 1984, 68: 258-9.

${ }^{92}$ Cowell JK, Hungerford J, Rutland P, Jay M: A chromosomal breakpoint which separates the esterase-D and retinoblastoma predisposition loci in a patient with del (13) (q14-q31). Cancer Cytogenet 1987, 27: 27-31.

${ }_{93}$ Mukai S, Rapaport JM, Shields J A Augsburger JJ, Dryja TP: Linkage of genes for human esterase $\mathrm{D}$ and hereditary retinoblastoma. $A m \mathrm{~J}$ Ophthalmol 1984, 97: 681-5.

${ }_{94}$ Cowell JK, Jay M, Rutland P, Hungerford J: An assessment of the usefulness of electrophoretic variants of esterase $\mathrm{D}$ in the ante-natal diagnosis of retinoblastoma in the United Kingdom. $\mathrm{Br} \mathrm{J}$ Cancer 1987, 55: 661-4.

${ }^{95}$ Dryja TP, Cavenee W, White R, Rapaport JM, 
Petersen R, Albert DM and Bruns GAP: Homozygosity of chromosome 13 in retinoblastoma. New Engl J Med 1984, 310: 550-3.

${ }^{96}$ Cavenee WK, Hansen MF, Nordenskjold M, Phillips RA, Gallie BL: Genetic origin of mutations predisposing to retinoblastoma. Science 1985, 228: 501-3.

${ }^{97}$ Cavenee WK, Murphree AL, Shull MM, Benedict WF, Sparkes RS, Kock E, Nordenskjold M: Prediction of familial predisposition to retinoblastoma. New Engl J Med 1986, 314: 201-7.

${ }^{98}$ Leppert M, Cavenee W, Callaham P, Holm T, O'Connell P, Thompson K, Lathrop GM, Lalouel J-M, White R: A primary genetic map of chromosome 13q. Am J Hum Genet 1986, 39: 425-37.

${ }^{99}$ Dryja TP, Rapaport JM, Epstein J, Goorin AM, Weichselbaum R, Koufos A, Cavenee WK: Chromosome 13 homozygosity in osteosarcoma without retinoblastoma. Am J Hum Genet 1986a, 38: 59-66.

${ }^{100}$ Hansen MF, Koufos A, Gallie BL, Phillips RA, Fodstad O, Brogger A, Gelle-Dahl T, Cavenee WK: Osteosarcoma and retinoblastoma: a shared chromosomal mechanism revealing recessive predisposition. Proc Natl Acad Sci USA 1985, 82: 6216-20.

${ }^{101}$ Draper GJ, Sanders BM, Kingston JE: Second primary neoplasms in patients with retinoblastoma. Br J Cancer 1986, 53: 661-71.

102 Lundberg C, Skoog L, Cavenee WK, Nordenskjold M: Loss of heterozygosity in human ductal breast tumours indicates a recessive mutation on chromosome 13. Proc Natl Acad Sci USA 1987, 84: 2372-6.

${ }^{103}$ Scheffer H, van der Lelie D, Aanstoot GH, Goor N, Nienhaus AJ, van der Hout AH, Pearson PL, Buys CHCM: A straightforward approach to isolate DNA sequences with potential linkage to the retinoblastoma locus. Hum Genet 1986, 74: 24955.

${ }^{104}$ Dryja TP, Rapaport JM, Joyce JM, Petersen RA: Molecular detection of deletions involving band q14 of chromosome 13 in retinoblastomas. Proc Natl Acad Sci USA 1986b, 83: 7391-4.

${ }^{105}$ Lalande M, Donlon T, Peterson RA, Liberfarb R, Manter S, Latt SA: Molecular detection and differentiation of deletions in band 13q14 in human retinoblastoma. Cancer Genet Cytogenet 1986, 23: $151-8$.

${ }^{106}$ Friend SH, Bernards R, Rogelj S, Weinberg RA, Rapaport JM, Albert DM, Dryja TP: A human DNA segment with properties of the gene that predisposes to retinoblastoma and osteosarcoma. Nature 1986, 323: 643-6.

${ }^{107}$ Lee W-H, Bookstein R, Hong F, Young L-J, Shew J-Y, Lee EY-HP: Human retinoblastoma susceptibility gene: cloning, identification and sequence. Science 1987a, 235: 1394-9.

${ }^{108}$ Fung Y-KT, Murphree AL, T'ang A, Quian J, Hinrichs SH, Benedict WF: Structural evidence for the authenticity of the human retinoblastoma gene. Science 1987, 236: 1657-61.
${ }^{109}$ Horsthemke B, Barnert HJ, Greger V, Passarge E, Hopping W: Early diagnosis in hereditary retinoblastoma by detection of molecular deletions at gene locus. Lancet 1987a, i: 511-2.

${ }^{110}$ Horsthemke B, Greger V, Barnert HJ, Hopping W, Passarge E: Detection of submicroscopic deletions and a DNA polymorphism at the retinoblastoma locus. Hum Genet 1987b, 76: 257-61.

111 Weissman BE, Saxon PJ, Pasquale SR, Jones GR, Geiser AG, Stanbridge EJ: Introduction of a Normal human chromosome 11 into a Wilms' Tumor cell line controls its tumorigenic expression. Science 1987, 236: 175-80.

112 Squire J, Dryja TP, Dunn J, Goddard A, Hofman T, Musarella M, Willard HF, Becker AJ, Gallie BL, Phillips RA: Cloning linked to the retinoblastoma locus on chromosome 13. Proc Natl Acad Sci USA 1986, 83: 6573-7.

113 Lee EYHP and Lee WH: Molecular cloning of the human esterase $\mathrm{D}$ gene, a genetic marker of retinoblastoma. Proc Natl Acad Sci USA 1986, 83: 6337-41.

${ }^{114}$ Lee W-H, Bookstein R, Wheatly W, Benedict WF, Lee EYHP: A null allele of esterase D is a marker for genetic events in retinoblastoma formation. Hum Genet 1987b, 76: 33-6.

${ }^{115}$ Koufos A, Hansen MF, Lampkin BC, Workman ML, Copeland NG, Jenkins NA, Cavenee WK: Loss of alleles at loci on human chromosome 11 during genesis of Wilms' tumour. Nature 1984, 309: $170-2$.

${ }^{116}$ Reeve AE, Eccles MR, Wilkins RJ, Bell GI, Millow LJ: Expression of insulin-like growth factor-II transcripts in Wilms' tumour. Nature 1985, 317: 258-60.

117 Orkin SH, Goldman DS, Sallan SE: Development of homozygosity for chromosome $11 \mathrm{p}$ markers in Wilms' tumour. Nature 1984, 309: 172-4.

${ }^{118}$ Fearon E, Vogelstein B, Feinberg A: Somatic deletion and duplication of genes on chromosome 11 in Wilms' tumour. Nature 1984, 309: 176-8.

${ }^{119}$ Raizis AM, Becroft DM, Show RL, Reeve AE: A mitotic recombination in Wilms' tumour occurs between the parathyroid hormone locus and 11p13. Hum Genet 1985, 70: 344-6.

${ }^{120}$ Flanagan JC and Di George AM: Sporadic aniridia and Wilms' tumor. Am J Ophthalmol 1969, 67: 558-61.

${ }^{121}$ Fraumeni JF and Glass AG: Wilms' tumor and congenital aniridia. Am J Cancer 1969, 19: 289.

122 Riccardi VM, Sujansky E, Smith AC, Francke U: Chromosomal imbalance in the aniridia-Wilms' tumour association: $11 \mathrm{p}$ interstitial deletion. Pediatrics 1978, 61: 604-10.

${ }^{123}$ Francke U, Holmes LB, Atkins L, Riccardi VM: Aniridia-Wilms' tumour association: evidence for specific deletion of $11 \mathrm{p} 13$. Cytogenet Cell Genet 1979, 24: 185-92.

${ }^{124}$ Fisher JH, Miller YE, Sparkes RS, Bateman JB, Kimmel KA, Carey TE, Rodell T, Shoemaker SA, Scoggin CH: Wilms' tumour-aniridia association: segregation of affected chromosome in somatic cell hybrids, identification of cell surface 
antigen associated with deleted area, and regional mapping of $\mathrm{c}-\mathrm{Ha}$-ras- $\mathrm{I}$ oncogene, insulin gene, and betaglobin gene. Somatic Cell Molec Genet 1984, 10: 455-64.

${ }^{125}$ Narahara K, Kikkawa K, Kimura S, Kimoto H, Ogata M, Kasai R, Hamawaki M, Matsuoka K: Regional mapping of catalase and Wilms' tumour-aniridia, genitourinary abnormalities and mental retardation triad loci to the chromosome segment $11 \mathrm{p} 1305-->\mathrm{p} 1306$. Hum Genet 1984, 66: 181-5.

${ }^{126}$ Michalopoulos EE, Bevilacqua PJ, Stokoe N, Powers VE, Willard HF, Lenin WH: Molecular analysis of gene deletion in anirida-Wilms' tumour association. Hum Genet 1985, 70: $157-$ 62.

127 Van Heyningen V, Boyd PA, Seawright A, Fletcher JM, Fantes JA, Buckton KE, Spowart G, Porteous DJ, Hill RE, Newton MS, Hastie ND: Molecular analysis of chromosome 11 deletions in aniridia-Wilms' tumor syndrome. Proc Natl Acad Sci USA 1985, 82: 8592-6.

${ }^{128}$ Boyd P, van Heyningen V, Seawright A, Fekete G, Hastie N: Use of catalase polymorphisms in the study of sporadic aniridia. Hum Genet 1986, 73: 171-4.

${ }^{129}$ Glaser T, Lewis WH, Bruns GAP, Watkins PC, Rogler CE, Shows TB, Powers VE, Willard HF, Gogven JM, Simola KOJ, Housman DE: The beta-subunit of follicle-stimulating hormone is deleted in patients with aniridia and Wilms' tumour, allowing a further definition of the WAGR locus. Nature 1986, 321: 882-7.

${ }^{130}$ Reeve AE, Housiaux PJ, Gardner RJM, Chewings WE, Grindley RM, Millow LJ: Loss of a Harvey rat allele in sporadic Wilms' tumour. Nature 1984, 309: 174-6.

131 Scott J, Cowell J, Robertson ME, Priestley LM, Wadey R, Hopkins B, Pritchard J, Bell GI, Rall LB, Graham CF, Knott TJ: Insulin-like growth factor-II gene expression in Wilms' tumour and embryonic tissues. Nature 1985, 317: 260-2.

132 Little MH, Ablett G, Smith PJ: Enhanced expression of insulin-like growth factor II is not a necessary event in Wilms' tumour progression. Carcinogenesis 1987, 8: 865-8.

${ }^{133}$ Schroeder WT, Chao L-Y, Dao DD, Strong LC, Pathak S, Riccardi V, Lewis WH, Saunders GF: Non-random loss of maternal chromosome 11 alleles in Wilms' tumors. A m J Hum Genet 1987 , 40: 413-20.

${ }^{134}$ Koufos A, Hansen MF, Copeland NG, Jenkins NA, Lampkin BC, Cavenee WK: Loss of heterozygosity in three embryonal tumours suggests a common pathogenetic mechanism. Nature 1986, 316: $330-4$.

135 Porteous DJ, Bickmore W, Chrisite S, Boyd PA, Cranston G, Fletcher JM, Gosden JR, Rout D, Seawright A, Simola KOJ, van Heyningen V, Hastie ND: H-Ras-1-selected chromosome transfer generated markers that localize aniridia and genitourinary dysplasia associated with translocation breakpoints and the Wilms' tumor gene within band 11p13. Proc Natl Acad Sci USA 1987, 84: 5355-9.

${ }^{136}$ Mannens M, Slater RM, Heyting C, Geurts van Kassel A, Goedde-Salz E, Frants RR, van Ommen GJB, Pearson PL: Regional localization of DNA probes on the short arm of chromosomes 11 using aniridia-Wilms' tumour associated deletions. Hum Genet 1987, 75: 180-7.

${ }^{137}$ Fearon ER, Feinberg AP, Hamilton SH, Vogelstein B: Loss of genes on the short arm of chromosomes 11 in bladder cancer. Nature 1985, 318: 377-80.

${ }^{138}$ Mukai S and Dryja TP: Loss of alleles at polymorphic loci on chromosome 2 in uveal melanoma. Cancer Genet Cytogenet 1986, 22: 45-54.

${ }^{139}$ Naylor SL, Johnson B, Minna JD, Sakaguchi A: Genetic analysis of chromosome 3 in small cell lung cancer. Abstracts, 7th International Congress of Human Genetics, Berlin, 1986, p 560.

${ }^{140}$ Mooibroek H, Osinga J, Postmus PE, Carritt B, Buys CHCM: Loss of heterozygosity for a chromosome 3 sequence presumably at 3 p21 in small cell lung cancer. Cancer Genet Cytogenet 1987, 27: $361-5$.

141 Zbar B, Brauch H, Talmadge C, Linehan M: Loss of alleles of loci on the short arm of chromosome 3 in renal cell carcinoma. Nature 1987, 327: 721-4.

142 Seizinger BR, Martuza RL, Gusella JF: Loss of genes on chromosome 22 in tumorigenesis of human acoustic neuroma. Nature 1986, 322: 644-7.

${ }^{143}$ Seizinger BR, De la Monte S, Atkins L, Gusella JF, Martuza RL: Molecular genetic approach to human meningioma: loss of genes on chromosome 22. Proc Natl Acad Sci USA 1987, 84: 541923.

${ }^{144}$ Solomon E, Voss R, Hall V, Bodmer WF, Jass JR, Jeffreys AJ, Lucibello FC, Patel I, Rider SH: Chromosome 5 allele loss in human colorectal carcinomas. Nature 1987, 328: 616-9.

${ }^{145}$ Dracopoli NC, Houghton AN, Old LJ: Loss of polymorphic restriction fragments in malignant melanoma: implications for tumour heterogeneity. Proc Natl Acad Sci USA 1985, 82: 1470-4.

146 Weissman SM: Molecular genetic techniques for mapping the human genome. Mol Biol Med 1987, 4: $133-43$.

147 Ray PN, Belfall B, Duff C, Logan C, Kean V, Thompson MW, Sylvester JE, Gorski JL, Schmickel RD, Worton RG: Cloning of the breakpoint of an $\mathrm{X} ; 21$ translocation associated with Duchenne muscular dystrophy. Nature 1985, 318: 672-5.

${ }^{148}$ Kunkel LM, Monaco AP, Middleworth W, Ochs HD, Latt SA: Specific cloning of DNA fragments absent from the DNA of a male patient with an X chromosome deletion. Proc Natl Acad Sci USA 1985, 82: 4778-82.

${ }^{149}$ Monaco AP, Bertelson CJ, Middlesworth W, Colletti C-A, Aldridge J, Fischbeck KH, Bartlett R, 
Pericak-Vance MA, Roses AD, Kunkel AD: Detection of deletions spanning the Duchenne muscular dystrophy locus using a tightly linked DNA segment. Nature 1985, 316: 842-5.

${ }^{150}$ Kunkel LM, Hejtmancik JF, Caskey T, et al.: Analysis of deletions in DNA from patients with Becker and Duchenne muscular dystrophy. Nature 1986, 322: 73-7.

${ }^{151}$ Brown WRA and Bird AP: Long range restriction site mapping of mammalian genomic DNA Nature 1986, 322: 477-81.

152 Van Ommen GJB and Verkerk JMH: Restriction analysis of chromosomal DNA in a size range up to two million base pairs by pulsed field gradient electrophoresis. In Davies KE ed. human genetic disease: a practical approach. Oxford, IRL Press, 1986, pp 113-33.

${ }^{153}$ Shaw DJ: A new strategy for mapping the human genome. J Med Genet 1987, 23: 421-4.

${ }^{154}$ Monaco AP and Kunkel LM: A giant locus for the Duchenne and Becker muscular dystrophy gene. Trends in Genetics 1987, 3: 33-7.

155 Barlow DP and Lehrach H: Genetics by gel electrophoresis: the impact of pulsed field gel electrophoresis on mammalian genetics. Trends in Genetics 1987, 3: 167-71.

156 Monaco AP, Neve RL, Colletti-Feener C, Bertelson CJ, Kurnit DM, Kunkel LM: Isolation of candidate cDNAs for portions of the Duchenne muscular dystrophy gene. Nature 1986, 323: 64650.

${ }^{157}$ Koenig M, Hoffman EP, Bertelson CJ, Monaco AP, Feener C, Kunkel LM: Complete cloning of the Duchenne muscular dystrophy (DMD) cDNA and preliminary genomic organisation of the DMD gene in normal and affected individuals. Cell 1987, 50: 509-17.

${ }^{158}$ Royer-Pokora B, Kunkel LM, Monaco AP, Goff SC, Newberger PE, Baehner RL, Cole FS, Curnutte JT, Orkin SH: Cloning the gene for an inherited human disorder-chronic granulomatous disease-on the basis of its chromosomal location. Nature 1986, 322: 32-8.

${ }^{159}$ Estivill X, Farrall M, Scambler PJ, Bell GM, Hawley KMF, Lench NJ, Bates GP, Kruyer HC, Frederick PA, Stanier P, Watson EK, Williamson R, Wainwright BJ: A candidate for the cystic fibrosis locus isolated by selection for methylation free islands. Nature 1987, 326: 840-5.

160 Orkin SH: Reverse genetics and human disease. Cell 1986, 47: 845-50.

${ }^{161}$ White R, Leppert M, Bishop DT, Barker D, Berkouritz J, Brown C, Callahan P, Holm T, Jerominski L: Construction of linkage maps with DNA markers for human chromosomes. Nature 1985, 313: 101-5.

162 Fuscoe JC, Clark LM, Van Dilla MA: Construction of fifteen human chromosome-specific DNA libraries from flow-purified chromosomes. Cytogenet Cell Genet 1986, 43: 79-86.

163 Poustka A, Pohl T, Barlow DP, Zehetner G, Craig
A, Michiels F, Ehrich E, Frischauf A-M, Lehrach $\mathrm{H}$ : Molecular approaches to mammalian genetics. Cold Spring Harb Symp Quant Biol 1986, 51: 131-9.

164 Poustka A, Pohl TM, Barlow DP, Frischauf A-M, Lehrach $\mathrm{H}$ : Construction and use of human chromosome jumping libraries from Not I-digested DNA. Nature 1987, 325: 353-5.

165 Vissing H, Grosveld F, Solomon E, Moore G, Lench N, Shenman N, Williamson R: Progress towards construction of a total restriction map of a human chromosome. Nucleic Acids Res 1987 , 15: $1363-75$.

${ }^{166}$ Bird AP: CpG-rich islands and the function of DNA methylation. Nature 1986, 321: 209-13.

${ }^{167}$ Cooper DN and Gerber-Huber S: DNA methylation and $\mathrm{CpG}$ suppression. Cell Differentiation 1985, 17: 199-205.

168 Gardiner-Garden $\mathrm{M}$ and Frommer M: CpG islands in vertebrate genomes. J Mol Biol 1987, 196: 261-82.

${ }^{169}$ Lindsay S and Bird AP: Use of restriction enzymes to detect potential gene sequences in mammalian DNA. Nature 1987, 327: 336-8.

${ }^{170}$ Myers RM, Lumelsky N, Lerman LS, Maniatis T: Detection of single base substitutions in total genomic DNA. Nature 1985, 313: 495-8.

171 Novack DF, Casna NJ, Fischer SG, Ford JP: Detection of single base-pair mismatches in DNA by chemical modification followed by electrophoresis in 15 per cent polyacrylamide gel. Proc Natl Acad Sci USA 1986, 83: 586-92.

172 Lerman LS, Silverstein K and Grinfeld E: Searching for gene defects by denaturing gradient gel electrophoresis. Cold Spring Harb Symp Quant Biol 1986, 51: 285-97.

${ }^{173}$ Gibbs RA and Caskey CT: Identification and localisation of mutations at the Lesch-Nyhan locus by ribonuclease A cleavage. Science 1987, 236: 303-5.

174 Scharf SJ, Horn GT, Erlich HA: Direct cloning and sequence analysis of enzymatically amplified genomic sequences. Science 1986, 233: 1076-8.

${ }_{175}$ Mullis K, Faloona F, Scharf S, Saiki R, Horn G, Erlich H: Specific enzymatic amplification in vitro: the polymerase chain reaction. Cold Spring Harb Symp Quant Biol 1986, 51: 263-73.

${ }^{176}$ Cooper DN and Youssoufian $\mathrm{H}$ : The CpG dinulceotide and human genetic disease. Hum Genet, (in press)

${ }_{177}$ Cooper DN: Eukaryotic DNA methylation. Hum Genet 1983, 64: 315-33

178 Cooper DN and Schmidtke J: DNA restriction fragment length polymorphisms and heterozygosity in the human genome. Hum Genet 1984, 66: $1-16$.

179 Youssoufian H, Kazazian HH, Phillips DG, Aronis S, Tsiffis G, Brown VA, Antonorakis SE: Recurrent mutations in haemophilia $A$ give evidence for CpG mutation hotspots. Nature 1986, 324: $380-2$. 